Portland State University

PDXScholar

\title{
Narratives of Native American Women and Tribal \\ Courts: the Framing of the Violence Against Women \\ Act of 2013 in Mainstream, Native American, and Tribal Press Coverage
}

Alesha Marie Sangster

Portland State University

Follow this and additional works at: https://pdxscholar.library.pdx.edu/open_access_etds

Part of the Domestic and Intimate Partner Violence Commons, and the Mass Communication Commons

Let us know how access to this document benefits you.

\section{Recommended Citation}

Sangster, Alesha Marie, "Narratives of Native American Women and Tribal Courts: the Framing of the Violence Against Women Act of 2013 in Mainstream, Native American, and Tribal Press Coverage" (2016). Dissertations and Theses. Paper 3316.

https://doi.org/10.15760/etd.3296

This Thesis is brought to you for free and open access. It has been accepted for inclusion in Dissertations and Theses by an authorized administrator of PDXScholar. Please contact us if we can make this document more accessible: pdxscholar@pdx.edu. 
Narratives of Native American Women and Tribal Courts:

The Framing of the Violence Against Women Act of 2013 in Mainstream,

Native American, and Tribal Press Coverage

by

Alesha Marie Sangster

A thesis submitted in partial fulfillment of the requirements for the degree of

Master of Science

in

Communication

Thesis Committee:

Cynthia-Lou Coleman, Chair

Cornel Pewewardy

Tanya Romaniuk

Portland State University

2016 


\begin{abstract}
The Violence Against Women Act is a legislation created to expand more legal rights and services to survivors of domestic violence or intimate partner violence. Frame analysis was used to examine the coverage of the Violence Against Women Act of 2013 in three genres of press media: mainstream press, Native American press, and tribal press. Based on the media frames produced in the three media genres, the legislation was presented as more of a conflicting or controversial issue in mainstream press through the use of the conflict frame and the "Indian as other" frame. But all news coverage also presented two emergent frames - the tribal sovereignty frame and the women's rights frame - that explained the importance of expanding tribal sovereignty in order to protect Native American women on reservations. The news coverage of VAWA 2013 in all press genres also included perspectives from federal and state governmental sources as well as perspectives from tribal governments, Native American organizations, and social service agencies. This report concludes by discussing the implications of the media frames and occupational source use in terms of the three media genres.
\end{abstract}




\section{Acknowledgments}

This research project is dedicated to victims and survivors of domestic violence/intimate partner violence. In recognizing this dedication, I also acknowledge the women in my family who helped raise me and inspired me to pursue my dreams. I pay tribute to the media organizations who are able to represent the underrepresented racial and ethnic groups in this country and around the world. I would like to acknowledge my husband and my graduate student cohort for providing me with the personal and emotional support that helped me pursue my academic endeavors. I also thank my thesis committee and the other influential people in my life who inspired me to pursue cultural studies, to look beyond myself and to look from the perspective of others. 


\section{TABLE OF CONTENTS}

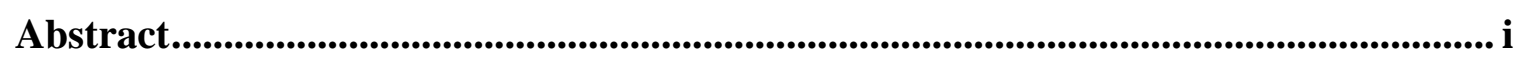

Acknowledgements ................................................................................................................................ ii

\section{Chapter 1}

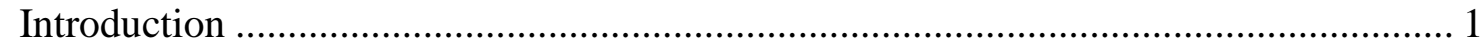

\section{Chapter 2}

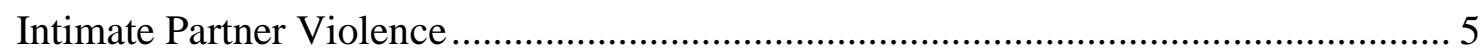

\section{Chapter 3}

The Media and the Social Construction of Reality

\section{Chapter 4}

The Media and Message Distribution.

\section{Chapter 5}

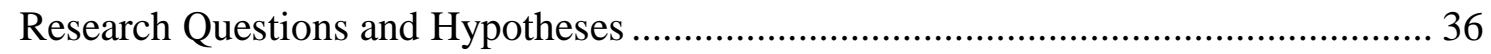

\section{Chapter 6}

Methods

\section{Chapter 7}

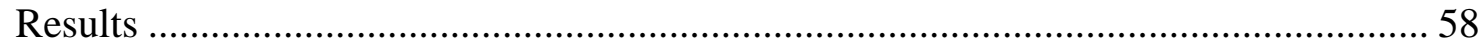

Media Frame Use in News Coverage .................................................................... 58

Source Use in News Coverage ................................................................................ 80

\section{Chapter 8}

Discussion. 


\section{Chapter 9}

Conclusion

References................................................................................................................................ 99

\section{Appendices}

A: Code Sheet for Frame Analysis .................................................................... 107

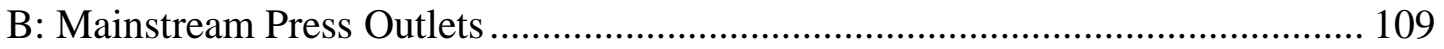

C: Native American and Tribal Press Outlets ........................................................ 110

D: Reference List for Article Data ........................................................................... 111 


\section{Chapter 1: Introduction}

"The only feeling that anyone can have about an event he does not experience is the feeling aroused by his mental image of that event. That is why until we know what others think they know, we cannot truly understand their acts." (Lippmann, 1922, p. 10)

When the public understands a public policy issue, they are able to determine whether the public legislation will be in the best interest of individuals directly affected by the policy. Since the public may have limited connections with groups of people immediately impacted by a policy or the government officials who help implement a law, the media serve as a tool to help the public understand how a piece of legislation affects the rest of society. One social issue that has been addressed more frequently in the past decades is intimate partner violence, also known as domestic violence. According to the Centers for Disease Control (2015), intimate partner violence affects millions of people every day, with women and certain racial minorities being the most vulnerable groups affected by the epidemic. One piece of legislation designed to address this public issue is the Violence Against Women Act (VAWA). The law was first implemented in 1994, and has been reauthorized in 2005 and in 2013.

The Violence Against Women Act of 1994 was created to expand more legal rights and services to victims of domestic violence and to produce strict penalties for perpetrators of violence. The Violence Against Women Act of 2013 (also called VAWA 2013) was an amended version of the original VAWA and was designed to include more 
specific protections for specialized groups of people; these groups include illegal immigrants, homosexual couples, and Native Americans living on reservations. ${ }^{1}$

VAWA 2013 was signed into law by President Obama on March 7, 2013 after the legislation passed through Congress, but the process of the legislation passing through Congress was also met with disagreements about $V A W A$ 's intent to serve Native communities. Title IX of VAWA 2013 gave tribal courts the power to prosecute Native and non-Native individuals who live and work on reservations and who also commit domestic violence crimes on reservations. One of the main criticisms of $V A W A$ is that the legislation gave too much legal power to tribal courts, which threatened the welfare of non-Native defendants who would be tried under tribal court jurisdiction with the law's passing.

VAWA 2013 could be considered one of the most important federal laws to be enforced on tribal lands since the law would give more protections to Native American victims of intimate partner violence, but without fully understanding the impact of the legislation, the general public may have had issues forming a consensus on whether the law should have been implemented. When the public has a shared understanding about a

\footnotetext{
${ }^{1}$ The terms Native American (or Native), Alaska Native, American Indian, and First Nations have been used to describe the tribes, bands, and nations in North America, while the terms Indigenous and Aboriginal have been used to describe tribes, bands, and nations located through the world. Indigenous and Aboriginal are terms that describe tribes that are were the original inhabitants of a specific geographic region before the arrival of outside groups (such as Europeans). Indigenous groups in the United States have been classified as a specific racial category with the terms Native American, Alaska Native, and American Indian, and have been most commonly used in scholarship and media coverage. For the purposes of this report, the terms Native American (or Native), Alaska Native, and American Indian will be used to describe groups classified as this specific racial category or as belonging to a tribe, band, or nation in the United States. Non-Native will also be used to describe groups or individuals classified into other racial categories (including White or European) and not officially enrolled in a tribe, band, or nation. The terms Indigenous, Aboriginal, and First Nations will also be used to describe groups in the U.S. and other countries (such as Canada).
} 
social issue, this allows individuals to address social problems and support legislation that try to alleviate the social problems (Sunstein, 2001). The role that the media played in VAWA coverage may have affected the public perception of the law, and specifically how the law applied to Native Americans.

The media's function is to attempt to convey information in an understandable fashion in order for the public to interpret and make judgments about a news topic. But because of the journalistic practices and agendas employed by the media, news content may convey a news story in a way that gives a limited picture about legislation. The way that a news story is composed may also give a limited perspective about a particular group of people, which may lead to stereotypes or misperceptions about individuals belonging to a specific group.

\section{Examining the Violence Against Women Act across Media Genres}

This research analyzed what role the print media played in terms of covering the Violence Against Women Act of 2013, and specifically focused on news coverage of VAWA's impact on Native American communities. This report also analyzed news coverage from three specific media genres of mainstream press, Native American press, and tribal press. The term "mainstream media" has been used to describe general interest media outlets that produce content for a heterogeneous and wide-ranging audience. Native American media (outlets owned by corporations or private individuals) and tribal media (outlets owned by specific tribes, bands, or nations) are specialized genres that specifically cover issues that directly affect Native communities. Based on these media 
agendas and functions, Native American press and tribal press may have a varying impact on how the public perceives the Violence Against Women Act in comparison to mainstream press.

From these aspects of media functions, the critical paradigm was used to examine how print media framed the Violence Against Women Act of 2013. Scholars who operate within the critical paradigm believe that certain sources may have more influence on journalistic practices and frame creation, and that these frames omit information that could have been retrieved from less influential sources (D’Angelo, 2002). Since the critical paradigm in media studies explores how the media create frames based on the perspectives held by powerful interest groups over others, this research examined how three types of print media genres (mainstream, Native American, and tribal media) framed the news discourse about the Violence Against Women Act of 2013 and how media agendas may have affected these frames.

This research was examined as a case study and used frame analysis to understand the depiction of VAWA 2013. The portrayals of Native and non-Native individuals as well as tribal courts was also be examined in this report. Based on the specific media agendas of three genres of press media-mainstream press, Native American press, and tribal press - the report analyzed the frames used in the coverage of the act, including the framing of the act in terms of conflict or controversy. 


\section{Chapter 2: Intimate Partner Violence}

The terms "domestic violence" and "intimate partner violence" have been used interchangeably in scholarly literature, governmental reports, and news coverage, and these terms will be used interchangeably throughout this report. According to the U.S. Department of Health and Human Services, domestic violence is also known as intimate partner violence, and involves one person in a relationship purposely hurting the other person in a physical, sexual, or emotional manner (womenshealth.gov, 2015). According to a Centers for Disease Control and Prevention report, intimate partner violence includes physical or sexual violence, threats of violence, stalking, or psychological aggression by a former or current intimate partner (Black, Basile, Breiding, Smith, Walters, Merrick, Chen, \& Stevens, 2011). Domestic violence can also involve progressive social isolation and intimidation of any sort, and the abuser's aim is to establish control over their victim (Rogers \& Giroux, 2012).

Intimate partner violence can affect men and women (although women are disproportionately affected by violence), homosexual couples, and non-cohabiting or cohabiting partners involved in a romantic or sexual relationship (Black et al., 2011). Intimate partner violence has also been associated with negative community-level factors such as poverty or violent crime (Carlyle, Savage, \& Babin, 2014), but intimate partner violence can be experienced by individuals of all races and socioeconomic backgrounds (Meyer-Emerick, 2002).

Some of the consequences of intimate partner violence both on the individual 
level and on the societal level include financial losses and increased health risks. In 2003, financial costs related to intimate partner violence exceeded $\$ 8.3$ billion; this cost included money spent on medical and mental health care as well as money from productivity loss (CDC, 2015). From this $\$ 8.3$ billion, $\$ 6.2$ billion included costs related to physical assault, $\$ 460$ million related to sexual assault, $\$ 461$ million related to stalking, and \$1.2 billion in the value of fatalities (CDC, 2015).

According to former surgeon-general Antonia Novello, the leading cause of injuries to women in 1992 was domestic violence abuses (Meyer-Emerick, 2002). Severe health conditions associated with domestic violence can be a result of direct physical violence or chronic stress received from the abuse (CDC, 2015). Health problems and issues can include traumatic brain injury, pelvic pain, and reproductive problems. Psychological problems associated with domestic violence include anxiety, depression, and symptoms of post-traumatic stress disorder. All of these risks and consequences can have severe impacts on society when a large number of individuals are victims of domestic violence and when these health risks pose productivity loss and money loss to the economy (CDC, 2015).

As stated earlier, women are disproportionately affected by intimate partner violence. According to national statistics on intimate partner violence victims from 2010 data (the report was published in 2011), more than one-third (35.6\%) of women and more than one-fourth $(28.5 \%)$ of men have experienced rape, physical violence, and/or stalking by an intimate partner in their lifetime (Black et al., 2011). Native American populations specifically have been the most vulnerable groups affected by domestic violence abuses 
when compared to individuals of other racial groups. ${ }^{2}$ Four out of every $10(46 \%)$

American Indian or Alaska Native women, and nearly half (45.3\%) of American Indian or Alaska Native men have been the victim of rape, physical violence, and/or stalking by an intimate partner in their lifetime (Black et al., 2011).

Little is known about the causes or nature of intimate partner violence in Native American communities (Matamonasa-Bennett, 2015). The next section will explore the scholarly works that have attempted to describe the nature of domestic violence in Native American communities, as well as the role that legislation (including VAWA) has played in attempting to protect Native American individuals in their communities.

\section{Violence and Indigenous Communities}

According to feminist and Indigenous scholars, the effects of European colonization on Indigenous groups are associated with intimate partner violence in internal family structures (Burnette, 2015; Chenault, 2011; Deer, 2004; MatamonasaBennett, 2015; A. Smith, 2005; Weaver, 2009). Colonized peoples can be defined as "inhabitants of the non-Western and non-European world that had been controlled and often settled forcibly by Europeans" (Said, 1989; p. 206) who are also encouraged or forced to adopt the belief systems of their colonizers (Weaver, 2009). This forced adoption of Anglo-European systems resulted in the disruption of traditional Indigenous

\footnotetext{
${ }^{2}$ For female victims of intimate partner violence abuses (which include rape, physical violence, and stalking) reported in 2010, 34.6\% were White, $43.7 \%$ were Black, 37.1\% were Hispanic, 19.6\% were Asian or Pacific Islander, and $46 \%$ were American Indian or Alaska Native. For male victims of intimate partner violence reported in the same year, $28.2 \%$ were White, 38.6\% were Black, $26.6 \%$ were Hispanic, and 45.3\% were American Indian or Alaska Native. 8.4\% of Asian or Pacific Islander victims reported physical violence abuses alone - estimates for all three forms of violence were not available or not reported. (Black, Basile, Breiding, Smith, Walters, Merrick, Chen, \& Stevens, 2011).
} 
cultures, knowledges, and systems, which has been transferred throughout multiple generations of Indigenous peoples (Chenault, 2011).

Systemic oppression from colonization has been enacted within Indigenous communities through the implementation of federal policies, which enforced European ideology onto Indigenous nations. Scholars suggest that European-Christian ideology exercised through federal policy implementation had resulted in the reduction of women's roles and abuses against Indigenous women. Ideologies-or the images or concepts that interpret or represent an aspect of reality-are naturalized perspectives that are performed unconsciously in society (Hall, 2015). Indigenous ideology practiced within tribal communities emphasized matriarchy (or female social roles) as well as cultural synthesis (Burnette, 2015; Chenault, 2011; Matamonasa-Bennett, 2015).

European-Christian ideology, on the other hand, influenced European men to abuse their female spouses for subordination and obedience. Christian ideology, which enforced patriarchy and dominance, was labeled as the superior ideology by Europeans, while Indigenous ideology, which emphasized matriarchy and communal relationships, was defined as inferior by Europeans; this reasoning was used as a justification for Europeans to oppress tribes and force patriarchal systems onto Indigenous communities (Chenault, 2011).

One of the ways that Christian ideology was transferred through Indigenous systems was through the use of federal allotment acts ${ }^{3}$ (Burnette, 2015; Weaver, 2009).

\footnotetext{
${ }^{3}$ The implementation of federal allotment acts required tribes to divide their communal lands by tracts and to have these tracts or allotments owned by heads of households in the tribes. Occasionally, tribal lands
} 
Before contact with Europeans, Indigenous women exercised powerful political influence in their societies and held high social, spiritual, and military positions (Burnette, 2015; A. Smith, 2005). But the roles of Indigenous women were reduced when Indigenous men were encouraged to own property and become heads of households through allotment acts (Burnette, 2015; Weaver, 2009). This resulted in the exercise of patriarchal systems within individual households and tribal communities, as well as the reduction of women's roles and abuse against Indigenous women within this exercise of patriarchy (Burnette, 2015; Chenault, 2011; Weaver, 2009).

One historical factor most commonly attributed to violence in Indigenous communities is the implementation of boarding schools, which began in the late 1800s (Adams, 1995; L. Smith, 2012). The role of boarding schools was to (re)educate Indigenous peoples under Anglo-European "civilized” teachings (Chenault, 2011). Boarding schools contributed to the reinforcement of gender roles established by colonial ideology, which emphasized subordination and obedience of women. (Chenault, 2011; Weaver, 2009). Students in boarding schools also suffered from physical and sexual abuse and endured abusive military discipline from school administrators (Adams, 1995; A. Smith, 2005). Students were sent back to their reservation homes in order to "civilize" and further oppress members of their tribe through knowledge and practices obtained from their education (Adams, 1995; Chenault, 2011). But boarding school implementation also led to fractured parent-child bonds, or differences between parents' Indigenous traditions and students' colonized/assimilated education (Adams, 1995).

were also sold by the tribes through these allotment acts and bought by the federal government (In U.S. and Canada) and White settlers (see also Harding, 2006). 
Scholars suggests that abuse suffered by Indigenous groups also contributed to inter-generational trauma, where the systemic oppressive experiences shared amongst Indigenous populations (such as boarding school implementation) contribute to further perpetuation of abuse throughout multiple generations (Burnette, 2015; Weaver, 2009). Abuse against women and children and the associating patriarchal ideology were in direct contrast with traditional Indigenous practices, but this transferred ideology and intergenerational trauma continue to manifest within Indigenous communities today (Burnette, 2015; Chenault, 2011; Matamonasa-Bennett, 2015; Weaver, 2009).

According to scholars, Indigenous communities had little to no incidents of domestic violence or intimate partner violence before colonization or European influence (Deer, 2004; Matamonasa-Bennett, 2015; A. Smith, 2005; Weaver, 2009). Historically, if cases of domestic violence were to occur, perpetrators were immediately and harshly punished for their crimes (Deer, 2004; Weaver, 2009). This discipline was needed because tribal communities encouraged unity and cooperation as a means of survival, and disputes within families would disrupt this unity (Matamonasa-Bennett, 2015). Although most Native American scholars agree that domestic violence was almost non-existent in pre-colonial societies, Matamonasa-Bennett (2015) stated that "it would be inaccurate and overly simplistic" (p. 21) to assume that individuals never faced cases of intimate partner violence before the influence of colonization.

Despite these possible connections between domestic violence and Indigenous communities, research has lacked a specific theoretical framework to study intimate partner violence in Indigenous communities (Burnette, 2015). According to Burnette 
(2015), past research has lacked empirical analyses that explore the relationship between intimate partner violence and historical traumatic experiences. But scholars have recently analyzed the underlying causes of domestic violence within Indigenous communities through the use of decolonizing methodologies (A. Smith, 2005; L. Smith, 2012), or perspectives used in research that is based on Indigenous ways of knowing. Previous scholars have used these methodologies in order to understand both causes and potential solutions to intimate partner violent rates in Indigenous communities (Burnette, 2015; Chenault, 2011; A. Smith, 2005).

Understanding the causes of intimate partner violence from an Indigenous perspective also helps explain the role that systemic factors (such as legislation enactment and tribal government powers) play in the causes and solutions to intimate partner violence in Native American communities (Indigenous groups in the United States). These systemic causes resulting from colonization also challenge the misperceptions about intimate partner violence that attribute violence to personal faults or cultural deficiencies (Chenault, 2011).

According to Deer (2004), the ability for tribal authorities to sanction perpetrators is essential in reducing domestic violence cases in Indigenous communities. According to Rogers and Giroux (2012), one of the main reasons why Native Americans are statistically more vulnerable to abuse on a national level is because of the jurisdictional limitations and lack of legal support given to Native American communities. The Violence Against Women Act of 1994, as well as its reauthorizations in 2005 and 2013, were created to provide specialized resources for victims of violence in this country, 
including Native American victims on reservations.

\section{The Violence Against Women Act: Implementation and Limitations}

Domestic violence was considered a public health issue in the 1970 s as a result of activism from medical professionals and feminist activists, who pressured the federal government to label the epidemic as a societal problem (Kozol, 1995). Also around this time, grassroots organizations and activists in Native American / Alaska Native communities provided shelter and support to Native individuals (Rogers \& Giroux, 2012). Activists also advocated for systemic and policy change by urging the public and government officials to rethink their perceptions about domestic violence (Rogers \& Giroux, 2012).

After years of activists lobbying specifically for the Violence Against Women Act, it was passed as an amendment to the Violent Crime Control and Law Enforcement Act of 1994 (Meyer-Emerick, 2002). The title "Violence Against Women Act" itself does imply that only women are (and were) protected under the legislation. The language of the 1994 act (Sec. 40302) specifies that the purpose of the legislation was to "protect the civil rights of victims of gender motivated violence" (The United States Congress, 1994). Meyer-Emerick (2002) also stated that VAWA 1994 was meant to protect female victims from abuses committed against men. But the reauthorization of VAWA in 2005 (Sec. 40002) clarifies that the act also covers male victims, and that the act does not "prohibit male victims of domestic violence, dating violence, sexual assault, and stalking from receiving benefits and services under this title," (The United States Congress, 2005). The main purpose of the Violence Against Women Act was to give individuals 
more protections from intimate partner abuses in public and private settings, as well as provide more legal sanctions against their abusers (Meyer-Emerick, 2002). These protections included harsher penalties for perpetrators of intimate partner violence, more legal sanctions for violating protection orders, and more pressure on local communities to abide by and enforce mandatory arrest policies (Meyer-Emerick, 2002). VAWA 1994 also provided specialized services to Native communities, which included providing federal funding to over 100 tribal governments for support, and enforcing foreign protection orders-or honoring protection orders across state lines or different reservations (Deer \& Tatum, 2003; Rogers \& Giroux, 2012).

\section{Tribal Courts and Tribal Sovereignty}

Despite the protections and services of VAWA, legal scholars argue that tribes struggle to enforce their sovereignty and exercise legal rights to protect Indigenous communities. According to Deer (2004), the ability for tribes to respond to crimes of sexual assault and intimate partner violence is connected to sovereignty, or the ability for tribes to protect citizens through the exercise of tribal governmental power. Andrea Smith (2005) also describes the definition of sovereignty that is based on "nation states" (such as the United States), where political power is exercised through "domination and coercion" (p. 129), and how this contradicts Indigenous sovereignty, which interconnects Indigenous practices, spirituality, and ways of knowing within individual tribes and their governments. Andrea Smith also states feminist scholars have called into question whether the "nation-state" model (as in the United States) is an appropriate model that should (and has been) adopted by tribal government because of these different definitions 
of sovereignty.

The relationship between the U.S. government and tribal governments also challenges ideas related to aspects of tribal sovereignty, which include tribal autonomy and self-determination. According to Brayboy (2005), tribal autonomy is the ability of tribes to have control over lands, territories, and natural resources, and self-determination is the ability of tribes to control their autonomy without "being forced to ask permission from the United States" (p. 434). Under the current system in the United States, tribal governments are still largely operated under U.S. federal jurisdiction, meaning that the federal government is able to establish laws that tribes can (or cannot) uphold in their individual tribal communities (Deer, 2004). One of the main loopholes in VAWA's original legislation is its failure to address crimes between Native American individuals and non-Native individuals, and this failure is tied to policies implemented by the federal government.

In 1968, Congress had passed the Indian Civil Rights Act, which outlined the powers of self-government in Native courts and jurisdictions (Deer, 2004; tribalinstitute.org, 2015). The Indian Civil Rights Act of 1968 recognized the same rights given under the U.S. Constitution's Bill of Rights, meaning that tribal courts had to grant individuals the right to due process or a fair trial (Deer, 2004; tribal-institute.org, 2015). But despite these guaranteed rights, the 1978 Oliphant vs. Suquamish Indian Tribe precedent would declare that tribal courts did not have the right to handle any criminal case involving non-Native individuals who worked or lived on reservations (Deer, 2004; tribal-institute.org, 2015). 
Under the Oliphant vs. Suquamish Indian Tribe precedent, tribal courts were allowed to handle cases involving Native Americans who are both members or nonmembers of the specific tribe that resides under the court's jurisdiction, but cases involving non-Native individuals would be transferred to federal courts (Deer \& Tatum, 2003; tribal-institute.org, 2015). This limitation also applied to domestic violence cases, where Native victims who were abused by non-Native individuals would have their cases transferred to federal courts (Deer \& Tatum, 2003). But this transfer usually delayed the prosecution of defendants. The delay was mainly the result of an overload of other court cases in federal judicial systems, which pushed the priority of domestic violence cases from reservations lower in the courts' systems (Rogers \& Giroux, 2012). Ultimately, failing to try abusers in domestic violence cases allows abusers to continue to commit their crimes on reservations (Rogers \& Giroux, 2012).

Once passed, Title IX of VAWA 2013 partially overturned the Oliphant vs. Suquamish Indian Tribe precedent, giving tribal courts the right to handle cases involving non -Native defendants (justice.gov, 2015; tribal-institute.org, 2015). Once VAWA was reauthorized, the Bill of Rights guarantee under the Indian Civil Rights Act of 1968 would automatically apply to domestic violence cases involving non-Native defendants (justice.gov, 2015; tribal-institute.org, 2015). The Indian Civil Rights Act of 1968 also included other legal rights and guidelines stated under one of the act's amendments, the Tribal Law and Order Act (TLOA) of 2010 (justice.gov, 2015; tribal-institute.org, 2015). The guidelines under TLOA mandated that tribal courts provide assistance of counsel (legal representation or other resources) for defendants, appoint law-trained tribal judges 
who are licensed to practice law, publicize tribal criminal laws and rules, and record all criminal proceedings conducted in tribal courts (justice.gov, 2015; tribal-institute.org, 2015).

Despite the progress of VAWA 2013 in serving certain domestic violence cases, the legislation could not cover specific crimes in Indian Country. Crimes that are not covered under VAWA 2013 include domestic violence crimes involving only non-Native individuals, physical or sexual abuse crimes involving individuals who are not in a committed relationship, and crimes committed by individuals who do not live or work on the reservation (justice.gov, 2015). Although VAWA 2013 allowed tribes to include nonNative individuals in their prosecution procedures in domestic violence cases, the Oliphant vs. Suquamish Indian Tribe precedent still holds today for other crimes not related to domestic violence (tribal-institute.org, 2015).

Deer (2004) asserts that sovereignty must be restored to tribal governments and tribal courts should be able to prosecute violent crime cases. Failures in the federal justice system to properly handle cases involving Indigenous communities have resulted in a growing need for tribal governments to obtain sovereignty and protect their Indigenous communities (Deer, 2004). Understanding the implications as well as the limitations of $V A W A$ as it applies to Native communities is essential in understanding why this legislation's reauthorization was so important to Native Americans. Public perception of both intimate partner violence and VAWA's implementation could have played an important role in whether $V A W A$ 's reauthorization gained public support. But the perceptions or misperceptions of this issue could have also deterred the legislation from 
passing and prevented Native victims from receiving adequate services to protect them from their abusers.

\section{Policy Making, Perceptions, and the Media}

A policy can be created as a result of the way a social problem is defined as well as who is responsible for causing or solving the problem (Meyer-Emerick, 2002). But an inaccurate definition or understanding of a social problem can also bring limits to the evaluation or implementation of a law meant to address the problem (Meyer-Emerick, 2002). This obstacle can further deter individuals affected by a social problem from receiving the resources they need to alleviate their plight (Meyer-Emerick, 2002).

One of the factors that influence the rate of intimate partner violence is the failure to attribute social responsibility to the problem. Government officials, as well as members of the general public, may fail to recognize implications of domestic violence or take any responsibility for preventing violence (Carlyle, Orr, Savage, \& Babin, 2014; Taylor \& Sorenson, 2005). As a result, individuals may attribute violence as an issue involving personal faults and where the victim and the abuser are responsible for causing and ending the violence (Carlyle et al., 2014; Kozol, 1995; Meyer-Emerick, 2002; Taylor \& Sorenson, 2005). Research has shown that news media largely portray domestic violence as a personal issue involving personal faults (stress, marital conflict) rather than a societal issue or systemic problem (Carlyle et al., 2008; Carlyle et al., 2014; Kozol, 1995; Taylor \& Sorenson, 2005). When the media depict domestic violence as cases of isolated incidents, they also fail to attribute broader societal contexts-such as the role of the government to protect victims, or historical oppression of Native communities-with 
the causes or solutions to domestic violence (Carlyle et al., 2008; Carlyle et al., 2014).

One of the main fallouts of intimate partner violence that directly affects Native communities is the failure in governmental legislation to protect victims of abuse. But despite the fact that domestic violence is a severe systemic problem for Native communities, misperceptions about intimate partner violence and VAWA's legal jurisdiction may cause confusion and lack of consensus among the general public. One important way that the public is able to receive information about social issues is through the media. If the media fail to give consistent portrayals and definitions to a social issue, this may deter a public consensus on how to address the issue and whether public policy is effective at solving the problem.

The next section of this report describes how the media can influence public perception by constructing social reality. Framing theory and critical theoretical perspectives will provide a theoretical framework in the role of reality construction and message distribution. 


\section{Chapter 3: The Media and the Social Construction of Reality}

The process of receiving information about an environment and interpreting this information to understand an environment is called the social construction of reality (Lippmann, 1922). Individuals understand the world around them through firsthand experience and through the reception of information from other sources (Lippmann, 1922; McQuail, 1987). According to Lippmann (1922), the public understands the world through the interpretation of incomplete accounts, and individuals interpret this incomplete information to form their own conclusions and perceptions about an event or issue. This is the formation of a pseudo-environment, or a pseudo-reality (Lippmann, 1922). The ideas that individuals have about a pseudo-environment may not entirely reflect the true environment or true reality of a situation, but individuals behave and respond to the true environment based on the beliefs they receive from their pseudoenvironment (Lippmann, 1922).

The main outlet that the public utilizes to receive information about the world is the media, and one of the main roles of the media is to act as a mediator to the general public. This includes journalists being able to report and interpret complex information in order for the general public to understand topical issues (Carey, 1997; McQuail, 1987). The public may not have physical access to public figures or may not experience certain topical issues firsthand (Lippmann, 1922; McQuail, 1987), so the role of the media is to give the public an image of aspects of the world that they are not personally exposed to. But according to Lippmann (1922), the media are not capable of providing the public with a complete picture of a news story since journalists are not able to retrieve and 
report every piece of information about a complex reality.

Part of shaping reality is that the media allow for multiple viewpoints to contribute to a public forum, which, according to Sunstein (2001), helps shape a wellfunctioning democracy. When individuals are exposed to alternative news items that were not originally sought, this allows individuals to learn more about issues outside of their immediate interest and build in their understanding of the world (Sunstein, 2001). This process of sharing multiple viewpoints in media discourse can be essential in terms of exposing the general public to views that may be absent or infrequently covered in mainstream news media (Johnson, 2010).

Despite the fact that the media can present multiple viewpoints in news discourse, one theoretical perspective, critical theory, argues that the media choose to present limited information to their audiences. This limitation is the result of the structural influences that drive journalistic practices and media content. Scholars have applied critical theory to framing analysis, and these scholars have claimed that social power has a direct influence on journalistic practices and reality construction. Under the framework of a critical paradigm, critical theory, critical race theory, and tribal critical race theory, can be used to guide framing scholars on how to interpret news reports based on social power abuse.

\section{Framing and Media Frames}

According to Entman (1993), framing occurs when an aspect of a perceived reality is made salient (noticeable, meaningful, or memorable) in communication. Entman states that the role of a written frame is to define a problem, diagnose the causes 
to a problem, make moral judgments, and suggest solutions to public issues. More specifically, a media frame is the organization of news stories through patterns of selection, emphasis, interpretation, and exclusion of information in the process of forming a cohesive story line (Carragee \& Roefs, 2004). According to Entman (1993), frames determine whether a social problem will be remembered by the public, how the audience understands a social problem, and how they will evaluate and act upon an issue. The creation of media frames also involves the selection and omission of specific information in a news story (Entman, 1993; Gamson \& Wolfsfeld, 1993).

Media frames can be created and identified by the structure of messages, overt and covert meanings to messages, and lexical features in talk or text; all of these elements can contribute to creating salience or importance in a news item (Entman, 1993). D’Angelo (2002) specifically describes how framing scholars use framing devices to identify news frames; framing devices can include discursive structures (words, language structure) or content formats (meaning behind language) found in news reports that aid in the creation of a media frame. Frames such as the conflict frame and the "Indian as other" frame have been used in previous framing studies (Coleman \& Dysart, 2005; Miller \& Ross, 2004; Price, Tewksbury, \& Powers, 1997; Vliegenthart, 2012). The conflict frame has been widely used in news coverage of political issues and can be identified by examining whether news items reflect disagreement between groups or individuals (Price et al., 1997; Vliegenthart, 2012). The "Indian as other" frame has been used to portray Native Americans specifically as either incompetent in decision making or inferior to White mainstream individuals or systems (Miller \& Ross, 2004). According to Miller and 
Ross (2004), this frame uses in-group/outgroup language, such as "they," "them," or "us," to describe Native Americans as inferior to or in opposition to Whites or AngloEuropeans.

Although journalists are known to have the ability to select information and create media frames, scant empirical research has explored the external factors or structural/organizational factors that influence journalists and their framing practices (Carragee \& Roefs, 2004; Scheufele, 1999). Some factors that may contribute to the creation of media frames include media organizational pressures or limitations (such as financial limits and deadline constraints), journalistic routines (such as source use), pressures of interest groups, or ideological or professional values of journalists (Scheufele, 1999). But despite these possible factors on media frame creation, scholars have neglected to empirically explain how some of these factors have directly contributed to the creation of media frames (Carragee \& Roefs, 2004; Scheufele, 1999). For example, Carragee and Roefs (2004) explain that researchers have failed to address how economic resources of interest group pressures can influence journalistic practices and media frame creation.

One of the main factors that has been emphasized in framing research has been the use of sources in relation to the use of media frames (Carragee \& Roefs, 2004; Scheufele, 1999). Entman (1993) states that frames in news stories can reveal "the imprint of power" (p. 53), meaning that frames can reveal the identity of sources and interest groups that are able to dominate the discourse of a news item. Journalists may choose to use sources known as official or elitist sources in their stories, or give these 
sources more credibility or access to news discourse (Carragee \& Roefs, 2004; D’Angelo, 2002). These sources are also known to be mainly White individuals who hold a great amount of social power-they have the ability to influence media discourse while simultaneously limiting the perspective of other sources or interest groups (Carragee \& Roefs, 2004; D’Angelo, 2002; van Dijk, 1996). Framing scholars have analyzed the types of sources that have been used in media coverage and how the language used by these specific sources contributes to the creation of media frames (Carragee \& Roefs, 2004; Scheufele, 1999). Framing scholars can be able to further examine the role of social power, source use, and media frame creation with the use of the critical paradigm and critical theory.

\section{Critical Theory and the Critical Paradigm}

Critical theory states that the influence of social power on news creation can lead to the construction of a particular reality that serves powerful interest groups (Carragee \& Roefs, 2004; D’Angelo, 2002; van Dijk, 1996). Critical scholars believe that interest groups are able to promote their ideologies through the media, but that marginalized groups in society are limited in influencing journalists and news content, specifically in the mainstream media (Carragee \& Roefs, 2004; van Dijk, 1996). Critical scholars also believe that this limitation also leads to a restricted presentation or perspective in news coverage, which affects the audience's understanding of a news item (Carragee \& Roefs, 2004; D’Angelo, 2002; van Dijk, 1996). Framing scholars who work within a critical paradigm-a model that examines social power abuse-can use critical theory to examine how the perspective of sources with great social power influence journalistic practices, 
which can in turn influence media frame creation (D’Angelo, 2002).

\section{Critical Race Theory}

Critical theory can be perceived as an overarching concept for the study of social power abuse. Critical race theory explicitly analyzes how race and racism relates to social power abuse. Since social groups can be defined as "marginalized" based on their race, critical race theory analyzes how social power abuse relates to the subjugation of racial minority groups. Critical race theorists define race as a social construction, where race is not dependent on biological traits, but racial categories are assigned to individuals and are subject to change over historical periods of time (Omi \& Winant, 2015). Racism is viewed as a set of collective projects that create and maintain dominance over groups assigned to particular racial categories (Hodges, 2015; Omi \& Winant, 2015).

Additionally, critical race scholars believe news discourse can contribute to racial ideologies, or naturalized perspectives about race and racism, in societal-level discourse, and affect the way the public perceives or accepts racism (Hodges, 2015; Olmstead, 1998).

\section{Tribal Critical Race Theory}

An additional theoretical perspective that can be used in relation to Indigenous groups specifically is tribal critical race theory (Brayboy, 2005). Tribal critical race theory addresses specific needs and issues concerning Indigenous communities, and addresses Native American groups (Indigenous groups in the United States) as a racial category as well as recognized sovereign nations; these aspects of tribal critical race 
theory have traditionally been absent under critical race theory analysis (Brayboy, 2005). Tribal critical race theory also specifically addresses colonization's consequences on Indigenous groups on a societal level (Brayboy, 2005). This theoretical perspective also defines power from an Indigenous perspective, which digresses from Western or AngloEuropean definitions of power. According to Brayboy (2005) power from an Indigenous perspective is rooted in the ability of a culture or ethnic group to define themselves and their traditions while understanding their position in society, and this ability is also called "an expression of sovereignty" (p. 435). Although tribal critical race theory has been commonly used in the field of education, this theoretical perspective can also be applied to other scholarly fields and disciplines (Brayboy, 2005).

\section{Intersecting Framing the Critical Theories}

Framing scholars who work under the critical paradigm believe that media frames are created from the perspectives of sources with social power instead of the perspectives given by marginalized sources (Carragee \& Roefs, 2004). Framing scholars who also use critical race theory can explain how racial minority groups defined as marginalized groups may not have the ability to contribute their perspectives to news reports or the creation of media frames.

From a tribal critical race theoretical perspective, framing scholars could also argue that Native American communities may have the ability to gain or exercise social power with the use of ethnic media and additional media frames produced by these media

outlets that challenge common mainstream media frames. Additionally, framing scholars 
who use critical race theory and tribal critical race theory may be able to explain how media frames and news practices, which omit information from tribal sources and racial minority sources, can contribute to broader news discourse that may perpetuate racial ideologies.

Although social power may influence media message production, critical race scholars also believe that societal racism can be challenged through the use of counternarratives or counter-dialogue to help define social reality (Olmstead, 1998). The role of Native American media and tribal media may include using counter-dialogues in examining news issues important to Native American communities and portraying these groups in a particular way through the use of these narratives. The media frames used in news coverage, as well as the types of sources used to create these frames, may be able to explain how the Violence Against Women Act of 2013 was portrayed in mainstream, Native American, and tribal press outlets. 


\section{Chapter 4: The Media and Message Distribution}

Mainstream media, in comparison to Native American media and tribal media, may play a different role in the social construction of reality if alternative frames, portrayals, or use of sources are presented with the news coverage of these media genres. Differences in these genres of media, such as media agendas, audiences, and source use, may contribute to the production of various media frames in news discourse. This section will explore differences in all three genres of media, and will also describe how Indigenous communities have been represented in news discourse in the past. Since little research exists on the representation of Native Americans in Native American media and tribal media, specific focus will be placed on mainstream media representations of Indigenous communities (in U.S. and Canada) seen in past media reports.

\section{Mainstream, Native American and Tribal Media}

The role of the media traditionally has been to provide information in the form of non-biased or objective reporting. These reports have often been called "general interest" stories, and have traditionally been meant to appeal to a large heterogeneous public (Carey, 1997; Sunstein, 2001). The initial role of the media was to expose the public to a wide range of topics while also allowing the public to have shared experiences from these reports, or come to a general consensus or agreement about topical news issues (Carey, 1997; Sunstein, 2001). Recently, scholars such as Matsaganis and Katz (2014) have used the term "mainstream media" to describe general interest media outlets that produce their content to a heterogeneous and wide-ranging audience. For the purposes of this report, 
the term "mainstream media" will be used to describe local and national media outlets produced to reach a heterogeneous audience.

Native American media and tribal media have been used interchangeably in past literature, but Daniels (2006) uses Native American media as an overarching term to describe media produced for Indigenous populations. Daniels (2006) also describes tribal media as organizations specifically owned by tribal entities. Qureshi and TrumblyLamsam's (2008) specific definition of "tribal print media" refers to the "official publications of the 561 federally recognized Native government entities (nations, tribes, or bands) in the United States" (p. 3). Native American media that are not tribally owned are typically owned by business corporations, non-profit organizations, or private individuals (Daniels, 2006). The publication News from Indian Country, for example, is owned by the organization Indian Country Communications. An example of a tribal media outlet owned by a specific tribe, band, or nation includes the Confederated Umatilla Journal owned by the Umatilla Confederated Tribes (also called the Confederated Tribes of the Umatilla Indian Reservation or CTUIR).

Both Native American media and tribal media function to cover Native American communities and issues (Trahant, 1995). Since Native American media and tribal media are created to serve Indigenous communities, they can also be defined as a type of ethnic media (Daniels, 2006; Johnson, 2010; Matsaganis \& Katz, 2014). One distinction between Native American media and tribal media relates to the local and national news issues covered in these genres. Tribal media specifically cover local news that affects local area tribes, and both tribal media and Native American media can cover national 
issues that relate to or affect Indigenous communities around the country (Daniels, 2006; Qureshi \& Trumbly-Lamsam's 2008).

\section{Native American Depictions in News Media}

Despite the growing number of racial minority coverage in mainstream media (Luther, Lepre \& Clark, 2012), as well as prior research on racial minority media representations, little scholarly research has examined how news media depict Native Americans (Miller \& Ross, 2004). Some of the research that has analyzed Native American representations in news coverage has concluded that news media have perpetuated inaccurate and stereotypical images of Native Americans in the press, both historically and throughout the $20^{\text {th }}$ Century (Daniels, 2006; Loew \& Mella, 2004; Luther, Lepre \& Clark, 2012; Weston, 1996).

According to Weston (1996), mainstream news practices concerning Native Americans have contradicted the function of the press to provide factual information to the public. And instead of challenging stereotypes, journalists have relied on and reinforced stereotypes related to Native Americans in their news coverage (Weston, 1996). Scholars suggest that one key aspect that contributes to these inaccurate depictions is the lack of knowledge about tribal history, culture, and sovereignty (Daniels, 2006; Loew \& Mella, 2005; Weston, 1996).

Conflict and otherness: Some of the stereotypes and inaccurate depictions seen in mainstream media coverage stem from the use of conflict in news coverage, as well as the labeling of Indigenous groups as "the Other" in news coverage. The category of 
"otherness" ultimately describes Indigenous communities and culture in opposition to, or inferior to, White and mainstream institutions (Coleman \& Dysart, 2005; Harding, 2006; Miller \& Ross, 2004). Issues of conflict and otherness are often interrelated in news coverage; stories typically involving conflict between Indigenous groups and mainstream society also involve the description of Natives as "the Other" in mainstream media.

According to Said (1989), under the premise of describing conflict between dominant and marginalized groups, individuals labeled as "the Other" can be classified as hostile or deviant from the dominant group, and in turn these ideals can justify taking action against "the Other" to either reform them or control and oppress them. "Otherness" and conflict have also been depicted through the "us vs. them" mechanism (Harding, 2006; Miller \& Ross, 2004; L. Smith, 2012; van Dijk, 1996; van Dijk, 2015), where mainstream media outlets (predominantly White-staffed) emphasize positive attributes of White mainstream society and downplay or dehumanize Indigenous societies.

Early depictions of savagery: Language of savagery or barbarism is documented to have emerged when Europeans made first contact with Indigenous tribes of the Americas in the late $15^{\text {th }}$ Century, and this language continued into the $16^{\text {th }}$ and $17^{\text {th }}$ centuries (Williams, 1989). One of the earliest conceptualizations of "otherness" was enhanced within Anglo-European society during the Enlightenment period of the mid$18^{\text {th }}$ Century, where scientists used classification systems to label Indigenous groups as inferior or savage (Omi \& Winant, 2015; L. Smith, 2012). Labeling Indigenous groups involved the creation of a human/savage dichotomy, where Indigenous groups were defined as "non-human," or lacking intellects or consciousness, in comparison to Anglo- 
Europeans (L. Smith, 2012). Terms associated with this classification included labels such as "savage," "barbaric," and "primitive" (L. Smith, 2012).

Early depictions of Native Americans related to conflict and otherness were perpetuated through the use of news media portrayals between the $17^{\text {th }}$ Century and early $20^{\text {th }}$ Century. The publication of Benjamin Harris' newspaper Publick Occurrences, Both Foreign and Domestick (published in 1690) created the distinction between "good and bad Indians," where "good Indians" supported the colonies and colonization at the time, and "bad Indians" resisted the colonies (Luther, Lepre \& Clark, 2012). Between the 1800s and 1900s, the language of "barbarism" would also include descriptions of Indigenous groups as "naïve or childlike" in American and Canadian presses (Luther, Lepre \& Clark, 2012; Harding, 2006). When British Columbian newspapers in Canada covered residential or boarding school implementation in the 1860 s, news reports framed Aboriginal peoples as inferior or as childlike by using the "us vs. them" distinction to describe or contrast Aboriginals to White settlers (Harding, 2006). According to Harding (2006), defining Aboriginals as inferior established the perception that settlers had the right to "re-educate" Aboriginals in the residential schools in order for Aboriginals to fit into society (Harding, 2006).

Credibility and inferiority: According to Williams (1989), the language of barbarism or inferiority was manifested through the rhetoric of federal policy implemented onto Indigenous communities in the United States during the $19^{\text {th }}$ Century. Government officials' exercise of political jurisdiction over Native American communities involved the use of legal discourse (which included speeches, documents, 
and articles). This legal discourse opposed assertions of tribal sovereignty-or the ability of tribes to utilize their land and resources-and labeled Native Americans as inferior to Anglo-Europeans (Williams, 1989). Legal discourse involved justifying colonizers' land claims to tribal territories by asserting that tribes were incapable of caring for land and territories compared to European settlers (Williams, 1989). This justification had also been used in news coverage of the 1800s to describe Indigenous tribes as incapable of taking care of land in territories located in Canada (Harding, 2006). Legal rhetoric of barbarism also described tribal sovereignty as "inconsistent to natural law" (p. 224) or was deviant or outside of European law and the "manifest destiny" ideology (Williams, 1989).

As news media discourse also continued to progress from the $19^{\text {th }}$ Century into the $20^{\text {th }}$ Century, language and ideologies associated with inferiority of Indigenous groups were still depicted in mainstream media coverage. One of the ways that contemporary mainstream media have depicted Native American culture and knowledge as inferior is through coverage of court hearings and the use of oral tradition stories in legal proceedings. In the Delgamuukw vs. the Queen court case of British Columbia, two First Nations tribes (Gixsan and Wet'suwet'en) sued the province over claims that 57,000 kilometers of land territory belonged to the tribes (Harding, 2006). But news reports emphasized the judge's decision to reject the tribe's oral tradition story as evidence in the case. The judge himself was depicted in the news coverage as highly credible, and this comparison to the judge was used to discount the Natives' credibility and claims in the case (Harding, 2006). 
A 1996 court case between Native American tribes and anthropologists also led to depictions of inferiority in news coverage. Pacific Northwest tribes attempted to prove that the 9,000-year-old skeletal remains found in Kennewick, Washington (later known as Kennewick Man) was of one of their ancestors with the use of their oral tradition story. But the news media depicted the scientists involved in the case as more credible than the tribes by framing science as more legitimate than the oral tradition story (Coleman \& Dysart, 2005).

War stories and war metaphors: The language of savagery and barbarism also continued to be used in the form of metaphors in news coverage. During World War I and World War II, stories that covered the efforts of Native Americans fighting in these wars included the use of the "noble and barbaric savage" depictions, where the "noble savage" was described as loyal or brave and the "barbaric savage" was described as cunning and deadly (Luther, Lepre \& Clark, 2012). News coverage that has depicted conflict between Native Americans and White mainstream society has also used stereotypical war metaphors. The coverage of the Kennewick Man case included the use of war and battle metaphors ("bones put Indians on the warpath," "modern day metaphor for cowboys and Indians") to describe the conflict between science and Indian tradition, and these linguistic structures were used to further emphasize the divide between the tribes and the anthropologists involved in the case (Coleman \& Dysart, 2005; p. 14).

Sovereignty, culture, and history in tribal media coverage: Although mainstream media have been known to produce inaccurate reports about Native Americans and their culture, the function of Native American media and tribal media has 
traditionally been known to allow Indigenous communities to challenge stereotypes depicted in mainstream media (Daniels, 2006; Loew \& Mella, 2005; Trahant, 1995). The lack of Native perspectives in mainstream news coverage has also encouraged Indigenous communities to form their own news publications and educate their audience about Indigenous culture (Daniels, 2006).

Tribal press specifically has covered information about tribal sovereignty, culture, and history in the depiction of tribal members. In Loew and Mella's (2005) content analysis of news stories that covered environmental issues, values related to sovereignty and treaty rights in tribal media reports emphasized the ability of tribes to protect their land and natural resources. Tribal members interviewed in the news coverage also expressed a cultural connection to their natural environment and explained this connection through the context of their creation or origin stories (Loew \& Mella, 2005). Articles also contained historical context, where the stories presented information in an historical chronological order or emphasized issues such as treaty rights or land claims (Loew and Mella, 2005).

Some of the functions of ethnic media are the emphasis on preserving cultural heritage, identity, and language (Johnson, 2010). Ethnic media can also encourage ethnic pride and discourage negative stereotypes typically found in mainstream media (Johnson, 2010). Native American media and tribal media may also inherit these functions in their agenda of serving Indigenous communities. Although the first tribal newspaper, the Cherokee Phoenix, was created in 1828 (Trahant, 1995), scholars have only recently begun to explore the news content published in Native American media and tribal media. 
But these outlets may play a role in emphasizing the importance of VAWA 2013 and depicting Native Americans differently compared to mainstream media coverage. 


\section{Chapter 5: Research Questions and Hypotheses}

The following research questions and hypotheses were derived from the theoretical framework introduced earlier in this report as well as information about the functions of mainstream, Native American, and tribal media genres. The research used media frame analysis to understand the types of frames that have been used in the depiction of the Violence Against Women Act of 2013. This report also used linguistic analysis (derived from critical discourse analysis studies) to examine how linguistic structures and meanings contribute to the media frames. Frame analysis and linguistic analysis were used to determine how Native Americans and tribal court systems were represented in comparison to non-Native individuals and the mainstream (federal) court system.

\section{Framing the Violence Against Women Act of 2013}

The purpose of news media is to act as intermediaries between world events and the general public who have limited exposure to these events. Native American media and tribal media specifically are responsible for covering issues and perspectives that resonate with Indigenous populations. Mainstream media attract general, heterogeneous audiences, but these outlets may also exclude certain perspectives of Native Americans in news discourse even when issues affect Native populations.

The Violence Against Women Act is an issue that affects Indigenous communities in the United States, and has been covered in all three genres of media. Journalistic practices and functions of each media may present the public with specific media frames that portray the legislation in different ways. These different frames can also produce 
different perspectives or select pieces of information, which can affect how their audiences understand the public policy. From this concern of media practice, the following research question was formed:

RQ1: How was the Violence Against Women Act Reauthorization of 2013 depicted in news coverage, and in what ways does coverage between mainstream, Native American, and tribal press compare with one another?

\section{The Conflict Frame}

One way that the media can frame a policy issue such as VAWA 2013 is to present oppositional sides concerning the issue, or to frame the issue as a debate or conflict. Media practitioners may believe that this type of depiction fairly introduces viewpoints that both support and opposes the legislation, but a conflict frame can also present limited information or exclude information of deeper issues surrounding legal protections of Native individuals on reservations. Controversy and conflict may be used as distractions to dissuade the general public (intentionally or unintentionally) from understanding a public policy issue and its benefits on a group of people.

The current study uses the critical paradigm to analyze whether VAWA 2013 was presented as more of a controversial issue in mainstream press coverage and less of a controversial issue in Native American and tribal press coverage. In analyzing controversy, this study examined whether the use of a conflict frame is presented more in mainstream press compared with Native American and tribal press. Past research has analyzed the conflict frame with political coverage, which can also include public policy discourse; the conflict frame has also been used to analyze disagreement between 
individuals or groups. Because mainstream media are known to emphasize conflict in coverage of Native American issues, these outlets may use a conflict frame to introduce disagreement about the policy. Native American media and tribal media, on the other hand, may not present VAWA 2013 as a controversial issue since the legislation would benefit Native American individuals.

Based on the function of the conflict frame, the following hypothesis was formed: H1: When comparing mainstream, Native American, and tribal press coverage of VAWA 2013, mainstream press will be more likely to present the issue as conflictual compared to Native American press and tribal press.

\section{The "Indian as Other" Frame}

The "Indian as other" frame, which has been used in past research and based on "otherness" depictions of Indigenous populations, will also be used in the analysis of VAWA 2013 coverage. According to Miller and Ross (2004), the "Indian as other" frame has been used to describe or represent Native Americans in opposition to or in contrast to Anglo-Europeans and systems. The frame uses in-group/out-group language to describe Native Americans-labeled as the outgroup-in contrast to Anglo-Europeans.

Based on the previous literature which describes "otherness," aspects of “otherness" have included Native Americans as less credible or less knowledgeable in comparison with Anglo European or mainstream systems (such as federal governments and courts). Depictions of "otherness" have also included portrayals of Native Americans as violent, vengeful, or threatening towards Anglo-Europeans and their systems; these 
portrayals have been described through the use of metaphors and in relation to issues concerning conflict or dispute between Native Americans and mainstream systems. Under the coverage of the Violence Against Women Act, tribal governments and tribal court systems may be perceived as either less credible (or incompetent) in comparison to the federal court system, or may also be perceived as a direct threat to non-Native defendants and their due process rights.

Based on previous portrayals of "otherness", two additional hypotheses were formed:

H2: In the coverage of VAWA 2013, mainstream press will more likely depict tribal court systems as less credible to the federal court system compared to Native American press and tribal press.

H3: In the coverage of VAWA 2013, mainstream press will also more likely depict tribal court systems as a threat to non-Native individuals compared to Native American press and tribal press.

\section{Source Use in the Press Genres}

Since sources contribute to the creation of media frames, additional analysis includes the study of source use in all three genres of press media. Previous media studies have claimed that elitist or official sources (politicians or parliamentary members) have largely contributed to news discourse or media frame creation, but little research has explored the use of other interest groups that have also contributed to frame creation (Carragee \& Roefs, 2004). Interest groups can also include professional or occupational organizations, and members of these groups may contribute to news discourse that 
directly affects the organizations they represent or the constituents they serve.

From this information, a conceptualization of source use will include individuals who are employed for specific organizations, which can include Native American or tribal organizations. The types of sources used in mainstream, Native American, and tribal press will help explain how conflict and "otherness" were depicted in the news coverage of VAWA 2013. Since little is known about source use in Native American media and tribal media, the types of sources used in the coverage may also contribute to a better understanding of the media practices of these two media genres in addition to mainstream media. From this information, a second research question about source use was formed:

RQ2: What types of organizational or occupational sources were used in the coverage of VAWA 2013 in mainstream, Native American, and tribal press? 


\section{Chapter 6: Methods}

The coverage of the Violence Against Women Act offers the context for the current case study of the legislation. According to McDougal (2014), a case study is "a detailed, intensive, and descriptive account of a single individual, group, or organization" and can also be "a time period" (p. 268). Case studies can explain the particularities of a phenomenon in great detail with the analysis of people, interviews, and documents (McDougal, 2014), and news coverage of VAWA 2013 includes document analysis of the legislation. The form of media analyzed in this report is print media, which includes primarily newspapers but also newsletters and magazines. Print media are one of the most common forms of media used for and by Native American tribes, and are also one of the only types of media that is controlled and owned by tribal entities specifically (Loew \& Mella, 2005; Qureshi \& Trumbly-Lamsam, 2008).

\section{Database Search of Articles and Publications}

Two databases were used to assess the sample of possible news outlets from all three genres which covered the legislation. The databases LexisNexis and Ethnic Newswatch were used to search for print media outlets. LexisNexis is a database that contains articles published in general interest news publications, and Ethnic Newswatch contains articles published in ethnic and Native news publications.

To retrieve the articles most relevant in this analysis, the keyword "Violence Against Women Act” was typed into the main search box of each database. Additional keywords related to Native Americans were also included in the database search. 
Indigenous groups in America have traditionally been classified as specific racial groups, with the terms Native American, American Indian, and Alaska Native to classify these individuals (Omi \& Winant, 2015). Indigenous groups are also identified as belonging to sovereign nations, tribes, and bands, with political and governmental recognition (L. Smith, 2012). Based on the past literature which define Indigenous groups in America by race and nation, specific terms which described this demographic were typed into the advanced options search box of each database. The terms typed in to the search boxes were "Native American," “American Indian," “Alaska Native," "Indigenous," and "tribe".

The database search was limited to a specific time frame: the searched articles collected for this analysis were published two years before VAWA's passing (from March 7, 2011), and two years after VAWA's passing (to March 7, 2015). This time frame limitation was done in both databases by selecting these specific dates in the "published before" and "published after" sections of the search engines. The March 7, 2011, time period was used because the legislation was first introduced in Congress in the year 2011. The March 7, 2015, time period was used because the number of articles retrieved from the database search declined around this time, and the legislation appeared to be less frequently reported because of this decline in coverage. (March 7, 2015 was also the date that the legislation took full effect, and all participating tribal governments were officially allowed to begin prosecution of non-Native individuals.) Analyzing articles within this time frame produced the most newsworthy and timely news coverage of the legislation during the process of its reauthorization in 2013. 
This analysis excluded news media outlets from other countries (or international outlets) and focused on U.S. media outlets. Under the LexisNexis database, these articles were excluded by selecting the United States section of the publication search tab, which only displayed newspapers printed in the U.S. Under the Ethnic Newswatch database, this exclusion was achieved by the analysis of each of the articles' abstract / details section, which listed the geographic location of each publication.

In terms of the information and content of the collected articles, the informational focus of each article was limited to the emphasis on Native American communities in relation to the legislation. Stories that focused on only general information about $V A W A$ or focused other groups (illegal immigrants or homosexual couples) affected by the legislation were excluded from this analysis; stories which largely conveyed information about Native American communities specifically and tribal court systems were included in this analysis. This inclusion and exclusion of articles required reading each article retrieved from the original database search and determining which articles had most of its content focused on describing VAWA in relation to Native American communities.

\section{Number of Articles Collected from the Database Search}

The LexisNexis search engine results from the mainstream press articles initially yielded a total of 332 articles. The 332 articles that included the key search terms (VAWA, Native American, etc.) were further analyzed by reading each article and determining whether the primary focus of each story described VAWA in relation to Native American communities. Because most of the original 332 articles failed to meet the story focus 
requirements, the total number of mainstream press articles included for the purposes of this report were 35 relevant articles $(\mathrm{N}=35)$.

The initial results from the Ethnic Newswatch search engine yielded 77 total articles. Of the 77 articles which included the key search terms (VAWA, Native American, etc.), stories which were eliminated from this report included articles published in other types of ethnic press outlets that were not Native American or tribal press outlets. Eliminated articles also included stories that did not focus on VAWA or the tribal provision in Native American or tribal press coverage. The final article analysis from this search included 26 total articles $(\mathrm{N}=26)$ : 10 articles from Native American press outlets and 16 articles from tribal press outlets. As a result of the article selection, the total number of articles from all three genres included in this analysis is 61 articles $(\mathrm{N}=61)$.

\section{Coding Procedures}

After all of the articles were collected, a code sheet was created and used as a guide to record information for this analysis (see Appendix A). The code sheet outlined specific information to record from the collected articles, and this included information about the publications and articles (media genre, media ownership, article publication dates), the media frames and corresponding linguistic structures identified in the article analysis, and the sources used in each article. Information identified in the articles (based on the code sheet guidelines) were recorded in three separate Microsoft Excel spreadsheets for each of the three media genres (mainstream, Native American, and tribal 
press genres). Specific details about the information retrieved from the examined articles will be described in the following sections.

\section{Press Outlet Coding}

Mainstream press outlets: Print outlets retrieved from the LexisNexis database were coded for whether the outlets were national or local. National press outlets cover news issues that affect the entire country. Local press outlets mainly cover issues related to a specific local community, but can also cover national issues. This categorization was used to examine possible differences between the frequency of local and national outlets that covered the legislation.

In terms of mainstream press outlets, the national outlets in the sample were the New York Times $(\mathrm{N}=2)$, the Washington Post $(\mathrm{N}=3)$, Roll Call-a political national newspaper $(\mathrm{N}=2)$, and the Christian Science Monitor $(\mathrm{N}=1)$. These outlets were the only national outlets retrieved from the LexisNexis database that also produced relevant articles used for this analysis.

The most commonly used local news outlets from this analysis include the Muskogee Phoenix located in Muskogee, Oklahoma (N = 5), the Turtle Mountain Star located in Rolla, North Dakota ( $=3$ ), the Bismarck Tribune located in Bismarck, North Dakota $(\mathrm{N}=3)$ and Grand Forks Herald located in Grand Forks, North Dakota $(\mathrm{N}=3)$ (see Appendix B for additional outlets). Local news outlets were the most common press outlets that covered the legislation in relation to tribal communities. This may be because 
the local offices of most of these outlets are also in close proximity to reservation communities.

Native American press and tribal press outlets: Print outlets retrieved from the Ethnic Newswatch database were labeled and coded separately based on the ownership of each medium. The Native American news outlets used in this analysis were the Native American Times $(\mathrm{N}=7)$, News from Indian Country $(\mathrm{N}=1)$, Sho-Ban News $(\mathrm{N}=1)$, and The Circle: News from an American Indian Perspective $(\mathrm{N}=1)$ (see Appendix C). Tribal media outlets used in this analysis were Au-Authm Action News $(\mathrm{N}=6)$, the Confederated Umatilla Journal $(\mathrm{N}=3)$, the Seminole Tribune $(\mathrm{N}=3)$, and the Cherokee Phoenix $(\mathrm{N}=2)$. One article from Char-Koosta News and one article from the Navajo Times were also included in this analysis (see Appendix C).

Identifying the differences between the Native American and tribal press outlets required reading company profiles and press ownership information, which were available from descriptions provided in the abstract/details section of Ethnic Newswatch. Ownership information not provided was obtained from the individual news outlets' websites or through Google search verification. Native American press outlets were classified and coded as owned by corporations, non-profit organizations, or private individuals (both Native and non-Native). Tribal press outlets were classified and coded as tribally-owned, or owned by a specific tribe, band, or nation.

\section{Article Coding}


After the 61 articles were collected, the articles were coded for additional features, such as whether they were news or editorial stories, Associated Press (AP) or other wire stories, and duplicate articles printed in the outlet genres. Articles were also labeled by their date of publication and author name.

News and editorial articles: News articles (also known as "hard news articles") as well as editorial articles were classified based on the labels used in the abstract/details section of each article listed under the search engine information. Most of the articles from all of the outlet genres were labeled and coded as news articles: mainstream press outlets contained 28 news articles, Native American press outlets contained nine news articles, and tribal press outlets contained 15 news articles $(\mathrm{N}=42)$. Mainstream press also contained seven editorials, while Native American press and tribal press contained one editorial each $(\mathrm{N}=9)$.

Associated Press $(A P)$ or other wire stories: $A P$ or wire story use was coded based on the byline description of each article. The use of these types of stories varied depending on the outlet genre. The mainstream press articles only included one $A P$ story and one other wire story (from Dakota Wire); one article (published in the Muskogee Phoenix) contained a combination of information from the Associated Press and from a Muskogee Phoenix reporter. Native American press articles included four AP stories, but some of the tribal press articles were more difficult to code. Some of the article bylines were listed as "From Washington," and did not explicitly list the story as an AP story or other specific type of wire story. These articles also did not contain specific names of reporters listed in the byline or article content, and were described as written by 
"Anonymous" in the search engine's abstract/details section. Because of this limitation, one story explicitly listed as $A P$ was coded as an $A P$ story, and six stories were coded and labeled as "From Washington."

Duplicate articles across outlet genres: Two duplicate articles were also discovered in the data collection and coded based on which media genres these articles were published in. One duplicate article was seen in one mainstream outlet and one Native American outlet. The mainstream newspaper Salt Lake Tribune published the article "Tribes make push for Violence Against Women Act", (Gamboa, 9 March, 2012), while the Native American press outlet Native American Times published the same article (which contained all of the same information and wording) under a different headline, “Tribes encourage support for Violence Against Women Act”, (Gamboa, 16 March, 2012). The article (published in both publications) was also labeled as an AP story. Despite the fact that this piece was a duplication, the article was coded as one article for the mainstream press genre and one article for the Native American press genre, which contributed to the total number of articles for each genre. Another duplicate article written by Lynda Mapes (writer for the Seattle Times) was used in both the Pittsburg Post-Gazette and the Charleston Gazette (Mapes, 25 February, 2013; Mapes, 15 March 2013), but for the purposes of this report, this article was only coded as one article since it only appeared in the media genre of mainstream press.

Dates of article publication: The date of publication of all of the 61 articles used in this report was available under each article's headline, and these dates were coded in the Excel spreadsheets. A noticeable amount of the articles from mainstream and Native 
American press outlets were published between February 1, 2013 and April 1, 2013, the time frame where VAWA was in the process of officially passing through the Senate and House of Representatives of Congress and signed by President Obama. Out of the 35 articles published in mainstream press, 16 articles were published between February 1, 2013 and April 1, 2013. Five out of the nine articles from Native American press outlets were printed between the same time frame. The articles printed in tribal press were more equally distributed throughout the dates, with six out of the 16 articles in tribal press printed between February 1, 2013 and April 1, 2013. Overall, five articles were printed in 2012, seven articles printed in 2013, and four articles printed in 2014 in tribal press.

\section{Frame Analysis and Linguistic Analysis}

For the purposes of this research, a list of linguistic structures, which have been used in previous critical discourse analysis studies, was created in order to identify specific linguistic structures or features that would contribute to the literature-based frames of conflict and "Indian as other". These structures were also used to identify any additional or emergent frames discovered from the news coverage. Literature-based frames are frames that have been used in previous framing studies, and the literaturebased frames of conflict and "Indian as other" were used in this analysis to examine the coverage of VAWA in all three media genres. Emergent frames are the frames that are discovered from information provided by news coverage, or frames that have not been previously used in past studies. After all of the articles were collected and after the list of linguistic structures was created, each article from all three media genres was read in 
order to identify the literature-based frames (conflict, "Indian as other") as well as additional or emergent frames.

\section{Application of Linguistic Structures in the Literature-based Frames}

Lexical features: Lexical features, such as word choice, expressions, and phrases, are the most common features identified in critical discourse analysis studies and framing analysis (van Dijk, 2015), and these linguistic structures were also the most commonly used tools in the analysis of the literature-based frames. According to Richardson (2007), lexical features or words can convey values or judgments that subjects hold in society. Lexical features also include the use of metaphors - perceptions or descriptions of one object/subject in terms of another object/subject (Richardson, 2007). War metaphors have previously been used in the analysis of news issues concerning conflict in relation to Native Americans (Coleman \& Dysart, 2007; Luther, Lepre, \& Clark, 2011).

In order to identify the conflict frame in terms of lexical features, specific words which conveyed dispute, disagreement, or opposition (such as argue, blame, and fight) were searched for during the reading of each article. Specific phrases and metaphors which described conflict (such as phrases which described "wars" or "battles") were also searched for in each article to identify the conflict frame. In order to identify the "Indian as other" frame, lexical features which described tribal courts as either non-credible or as threatening were searched for during the reading of each article. These included adjectives such as "incapable" or "not equipped" in terms of the credibility of tribal 
courts, as well as words such as "fear," "danger," or "threat," which signified tribal courts as threatening to non-Native individuals.

In-group/out-group language: The use of in-group/out-group language, or the "us vs. them" schema, has been used in previous literature (Harding, 2006; Miller \& Ross, 2004), and was originally conceptualized as the ideological square by van Dijk (1996, 2015). Language within this schema emphasizes (or foregrounds) the positive qualities of the in-group while emphasizing (or foregrounding) the negative qualities of the out-group (Richardson, 2007; van Dijk, 1996, 2015). This schema also minimizes (or backgrounds) the negative qualities of the in-group while minimizing (or backgrounding) the positive qualities of the out-group (Richardson, 2007; van Dijk, 1996; 2015).

In-group/out-group language was used in the coverage of VAWA to simultaneously convey both the conflict frame and the "Indian as other" frame. In order to identify the literature-based frames through in-group/out-group language, the use of the pronouns which describe outgroups (they, them, their) and pronouns which describe in-groups (we, us, our) were searched for during the article readings, and the use of these pronouns were attributed to a specific person source cited in each article. Identifying the conflict frame required examining how in-group/out-group language conveyed disagreement or dispute (with the use of lexical features and other linguistic features) between subjects in the process of foregrounding and backgrounding attributes.

In terms of the "Indian as other" frame, in-group/out-group language was specifically used to identify this frame by examining how specific sources (primarily 
federal government officials) foregrounded the positive attributes of the federal court system, while foregrounding the negative attributes of tribal court systems. In-group/outgroup language was also used to examine how specific (federal government official) sources backgrounded the negative attributes of the federal court system, while backgrounding the positive attributes of tribal court systems. Although in-group/outgroup language was used in order to identify the "Indian as other" frame in the articles examined in this report, the articles which did contain the "Indian as other" frame used more explicit outgroup language and pronouns (they, them, their) in the description of tribal courts and tribal governments, and used less explicit in-group language and pronouns (us, our, we) in the description of the federal court system.

Subjects and transitivity: The use of subjects (agents) and transitivity structures of sentences were also used to identify the literature-based frames. According to Richardson (2007), transitivity "forms the very heart of representation," and describes "relationships between participants and the roles they play in the process described in reporting" (p. 55). Messages that describe or represent transitivity typically consist of a subject (or agent), an action or process (performed by or to the subject), and the circumstances associated with the process (Richardson, 2007). Identifying the conflict frame with the use of transitivity in sentence structure required the search for specific subjects mentioned in the news coverage (Republicans, Native American women) and corresponding verbs describing action (dispute, disagree, argue) of these subjects. The "Indian as other" frame was also identified by searching for passages in the articles which 
described tribal courts with the use of specific verbs that conveyed threat (violate, threaten).

Modality and modal words: Modality (Richardson, 2007) is another linguistic feature that was used in this analysis. Modality conveys judgments, opinions, or attitudes in talk and text, and describes the certainty of a speaker's claim. Modality is communicated through the use of modal verbs (such as should, will, or must) as well as adverbs (certainly, definitely) in talk and text. Identifying modality in the conflict frame involved searching for modal words (will, must, certainly) which conveyed support or disapproval of passing the legislation. These modal words were also searched for in relation to tribal courts and threat (e.g.: tribal courts will violate Constitutional rights), and the capabilities or competence of tribal courts (e.g.: tribal courts will fail to ensure due process rights).

Implicit meaning: Linguistic tools can be used to convey both explicit and implicit meaning in talk and text. Implicit claims or meanings can be embedded in explicit features such as sentence structure or verb and adjective use (Richardson, 2007). Examples of linguistic features that convey both explicit and implicit meanings include implicature (an intended message of a speaker) and presupposition (an unintended or unnoticed message of a speaker) (Richardson, 2007, McConnell-Ginet, 2014).

For the purposes of this report, implicit or implied meaning will be identified by analyzing the absence of words or phrases (lexical features) that could have been used in a statement, as well as analyzing opposite or reverse labels not explicitly stated in a 
passage. For example, a statement that claims that "VAWA will be passed" (an explicit claim) also conveys that the legislation will not be rejected in Congress or vetoed by the President (hidden or implied claims). Implicit claims were used in the identification of conflict or dispute about the legislation and were used to describe tribal courts as threatening and less credible in the coverage of $V A W A$. Implicit claims were more frequently identified in the examination of the "Indian as other" frame. Implied content in "otherness" descriptions may had been used in order to avoid explicitly labeling tribal courts as deviant or threatening, and sources (primarily government officials) may had used implicit claims to preserve their positive self-presentation. Specific examples of implicit claims or meanings are given with the use of other linguistic tools (such as lexical features) in the Results section.

\section{The Examination of Emergent Frames}

The identification of emergent frames required a pilot study that initially examined a sample from the articles collected for the analysis. In the pilot study, 20 of the 35 mainstream press articles $(\mathrm{N}=20)$ were read to identify common patterns or themes that emerged from the article content. After the themes were recognized, specific emergent frames were created from this pilot study based on these themes and linguistic structures found in the articles. The emergent frames were further identified and conceptualized in the analysis of the remaining articles produced in the three media genres. The most common linguistic structures that identified the emergent frames were lexical features, but the other linguistic features listed above were also used in the 
identification of the emergent frames. Specific details about the detection of the emergent frames are described in the Results section.

\section{Articles which Conveyed "No Frame"}

Some of the articles in this analysis were also coded as presenting "no frame," meaning no detectable literature-based frame or possible emergent frame were identified from these articles. Stories coded and labeled as "no frame" articles presented general information about either $V A W A$ or other legislation related to VAWA and tribal communities (the Tribal Law and Order Act, the Indian Civil Rights Act). Some of these articles also described general information about tribal court jurisdiction before and after VAWA's passing. These articles displayed little to no explicit support or disapproval of the passing of the legislation. Some of the articles did present some of the linguistic features that were seen in the stories with the media frames. But the "no frame" articles did not prevalently consist of these items throughout their language as in the media frame articles.

\section{Source Coding and Source Description}

Occupational categories: Source coding was primarily focused on person source use, and sources were coded for their specific occupational titles and specific organizations that they represent. For each person source identified in each article, the full name of each source (given in the articles) was listed in the excel spreadsheets along with his or her occupational title and organization (given in the articles). 
Once all of the sources were coded, similarities in the types of organizations listed in the Excel spreadsheets (government, legal, non-profit) were identified. These similarities were based on the similar functions of these individual organizations described in the articles (such as providing legal assistance) as well as the specific constituent group that these organizations serve, also described in the articles (Native American communities, specific tribal communities, victims of domestic violence etc.). From these similarities, specific "occupational categories" were created, and sources were then coded and grouped as belonging to these specific occupational categories based on the organizations that these sources represented. The types of sources classified in four specific occupational categories were the sources that were most commonly seen in the news discourse. The description of these four occupational categories will be described in full detail in the Results section.

Source Attribution: Additional analysis also considered source attribution in each article. Source attribution is where journalists show or indicate where the information conveyed in an article comes from, as well as describe under what context (setting or circumstance) journalists were able to retrieve their information. Source attribution in this report examined how the reporters of each article were able to obtain the information and statements from each person source. If statements made by sources appeared to be originally obtained from the reporter him or herself, these sources were listed as "directly attributed" by the reporter. These statements would had been obtained through an interview between the reporter and their sources. These sources are also explicitly listed in the articles along with their corresponding statements or information. 
If source statements appeared to be made in a different context and obtained by the reporter from this context, these sources were labeled as "indirectly attributed" by the reporter. These various contexts include information from sources which were originally posted in a written or published statement, on a website or web blog, from other articles or broadcasts, or from specific previous moments in time. Reporters who obtained information though these contexts did not directly interview the original person source who made these statements, but retrieved the statements under these various contexts or mediums. Reporters who used indirect attribution of sources also explicitly state in the articles where the source information was retrieved; articles included descriptions of sources who made their claims "in a written statement", "at a Congressional meeting" during a specific date, or "during a visit" to a particular place. 


\section{Chapter 7: Results}

For the purposes of this report, the results will be discussed in two sections. The first section will address the first research question and associating hypotheses related to the frames seen in the collected articles. The second section will address the second research question and describe the types of sources used in the three genres of print media, as well as how these sources possibly contributed to the creation of news content.

\section{Media Frame Use in News Coverage}

The first research question addressed the media frames (literature-based and emergent frames) that may be seen in the news coverage of all three press genres. In order to compare mainstream press coverage to both the Native American press and tribal press coverage in examining the first research question, articles from both Native American press $(\mathrm{N}=10)$ and tribal press $(\mathrm{N}=16)$ were grouped collectively in the analysis of this report $(\mathrm{N}=26)$. Chi-square tests were used to examine the statistical significance for the literature-based frames, with a significance value of .05 set for the analysis of both literature-based frames. Chi-square tests were calculated through Williams and Monge's (2001) guide and description of nonparametric tests. ${ }^{4}$

\section{The Conflict Frame}

The first hypothesis predicted that the conflict frame (one of the literature-based frames) would be used more in mainstream press in comparison with Native American

\footnotetext{
${ }^{4}$ The statistical significance ( $\mathrm{p}$ value) of both frames were calculated using the chi-square formula, then referencing chi-square values and degrees of freedom to Williams and Monge's (2001) Table C (p. 222) to identify whether the significance value was between .05 and .025 .
} 
press and tribal press. A chi-square test showed the difference between mainstream press in comparison with Native American press and tribal press combined was not statistically significant $\left(x^{2}(1)=.53, \mathrm{p}>.05\right)$. Despite the fact that the difference between the press genres was not statistically significant, the conflict frame was more frequently seen in mainstream press coverage than in Native American press and tribal press coverage combined. In mainstream press, $23 \%$ of the articles (eight out of the 35 articles) contained the conflict frame. With Native American press and tribal press combined, $15 \%$ of the articles (four out of the 26 total articles) presented the conflict frame. One of the articles in Native American press that presented this frame was a duplicate / AP article also published in mainstream press. Two tribal press articles presented the conflict frame in conjunction to one of the emergent frames (the women's rights frame discussed later in this report).

The main function of the conflict frame in relation to the news coverage emphasized division amongst party lines (or between Democrats and Republicans). Other specific cases of the conflict frame include conflict between Native Americans / Alaska Natives and federal government representatives specifically. The linguistic structures identified in each article provide evidence of the prevalence of conflict.

Labels and lexical features for conflict: The duplicate article published in the Salt Lake Tribune and the Native American Times (Gamboa, 9 March, 2012; Gamboa, 16 March, 2012), stated that the Democrats "ruined" the bill (referring to VAWA) as a result of democratic leaders adding the tribal court provision to the legislation. This rhetorical strategy places blame on one party (or Democrats) in comparison to another party (or 
Republicans). Other common lexical features used throughout coverage which conveyed conflict include words such as "fight," "argue," "blaming," and "battle" over the process of passing the bill. The word "attack" was specifically used to describe Representative Kevin Cramer as "verbally attacking” Spirit Lake Tribal Council members at a public forum (Haga, 29 March, 2013; Haga, 30 March, 2013). When used in this context, the word "attack" was used as a transitive verb and conveyed action against a specific tribe.

Phrases and metaphors for conflict: Specific phrases and metaphoric language also contributed to the conflict frame in the news coverage. One mainstream press article titled "Noem opposes listing Native women in anti-violence bill” (Ross, 27 April, 2012) described VAWA as having "politicizing and isolating language" and that "all" individuals are already included in the Republican version of $V A W A$, (or the version without the tribal provision). This information implies that the Democrat version of the bill containing the tribal provision was specifically meant to cause strife or division because the tribal provision was "exclusionary" and only attempted to aid Native Americans.

The debate over passing VAWA was also described as a "rhetorical war" in another mainstream press article (Strong, 16 May, 2012), specifically referring to the language or content of the bill and the tribal provision as the cause of conflict between the two political parties. One New York Times article (Weisman, 11 February, 2013) also described the bill as "being held hostage", but specifically held "hostage," by the inclusion of the tribal provision. This metaphor of "being held hostage" also personifies 
the bill itself-since hostages are often associated with individuals- and is described as an entity constrained against its own will.

\section{Conflict between a federal government official and Alaska Natives: The}

Washington Post article, “Senator from Alaska reverses her divisive stance on women's law" (Horwitz, 3 August, 2014) describes conflict between Alaska Senator Lisa

Murkowski and Alaska Natives specifically. This article describes an additional element to the controversy of VAWA known as "the Alaska exemption." The "exemption" was a provision added by Murkowski into the legislation, which exempted Alaska Native tribes from VAWA protections. The rationale behind exempting Alaska Native villages from VAWA protections involves long-standing issues with Alaska Native tribes obtaining federal recognition of tribal sovereignty and exercising tribal court jurisdiction because of this ambiguity in federal recognition. Some Alaska Native villages do not receive the same governmental protections given to federally-recognized tribes in the other 49 states. (The "Alaska exemption" in VAWA was removed in 2014).

The article describes the legislation as being "heralded" by President Obama, but that Murkowski was "pressured by Alaska Natives" to repeal the provision. The word "heralded" describes $V A W A$ as a favorable piece of legislation according to the President (or the leader of the country). But the word "pressure" introduces conflict or tension, specifically between Murkowski and Alaska Natives, by describing that Alaska Natives were "forcing" Murkowski to repeal the exemption. The article continues to state that Murkowski's final decision to repeal the provision was "subject to much debate in Alaska," and that the exemption had "reopened a contentious debate" about jurisdiction 
and Alaska Native villages. The issue in this passage is labeled as a "contentious" or controversial issue that invokes "debate" or dispute. The article continues by stating that “Alaska Native women protested" the exemption, and the Indian Law and Order Commission called the exemption "unconscionable" or unreasonable. This also introduces Alaska Native women specifically and a Native American organization that oppose and challenge the exemption, and by extension Murkowski herself.

Conflict or threat against Native and non-Native individuals: One article published in the Native American Times (Abrams, 1 March, 2013) describes conflict between specific groups or agents (non-Native and Native individuals) and pseudo agents (more abstract subjects, such as "the tribal provision" or "the federal court system"). The article "Republicans offer deal on American Indian courts" (1 March, 2013) was published during the time period where VAWA was passed in the Senate and awaiting a final vote in the House of Representatives. The article stated that the renewed Republican version of the bill would allow defendants to request their cases be moved to federal court "if they felt their constitutional rights were being violated." This phrase presents the verb "violated" along with a passive sentence structure, or a sentence written in pasttense, with the use of the word "were". This passive sentence transformation and verb usage removes specificity in the statement, and implies that tribal courts (the absent subject) will threaten the constitutional rights of non-Native defendants, labeled as "they" (the present subject in the sentence).

This statement describes conflict between the process of passing VAWA with the tribal provision and non-Native individuals themselves. The article also described the 
current federal legal system as "broken" and uses modal word "will" to describe how Native American women "will continue to suffer unless Congress acts," or passes the bill with the tribal provision. In this context, the article also conveys conflict between a "broken" or insufficient federal court system and women victims of domestic violence specifically, presenting a threat or danger to Native American women.

This article describes how conflict also introduced the element of "threat" between specific entities affected by the legislation. The next section specifically addresses the element of "threat" with the use of the "Indian as other" frame. This frame specifically addresses the subject of non-Native individuals and the passing of the legislation with the tribal provision. Tribal courts and tribal governments are also depicted under this frame as posing a threat towards these individuals.

\section{The "Indian as Other" Frame}

The second and third hypotheses claimed that depictions of "otherness" would be presented more in mainstream press coverage in comparison with Native American and tribal press coverage through the "Indian as other" frame. The second hypothesis stated that the "Indian as other" frame would be conveyed through the depiction of tribal courts as less credible in comparison to the federal court system. The third hypothesis stated that this frame would also be conveyed through the depiction of tribal courts as more threatening to non-Native individuals in comparison to the federal court system.

A chi-square test was used to examine the second and third hypotheses combined under the "Indian as other" frame. When the two hypotheses were tested together, the 
chi-square analysis showed the difference between mainstream press in comparison to Native American press and tribal press combined was also not statistically significant $\left(x^{2}(1)=3.18, p>.05\right)$. But despite the absence of statistical significance, mainstream press coverage presented the "Indian as other" frame in four of the 35 published articles (11\% of articles), while the "Indian as other" frame was not seen in neither Native American press nor tribal press coverage. The "Indian as other" frame was also seen in conjunction to the conflict frame in mainstream press coverage, meaning that all four of the articles which presented the "Indian as other" frame also contained the conflict frame.

Some of the lexical features in the text of the articles simultaneously conveyed aspects of both conflict and "otherness" when describing VAWA and the tribal court provision. The "Indian as other" frame was also identified mainly through specific, detailed descriptions of the tribal provision. Articles which presented this frame contained statements which claimed that giving tribal courts the power to prosecute nonNative defendants would threaten due process regulations and the constitutional rights of these defendants. Some of these claims justified this threat by describing tribal court systems as incompetent or incapable of handling these specific cases. These claims were used to describe tribes and their court systems in juxtaposition to the federal court system; tribal courts were labeled as ineffective and threatening, and the federal court system (either explicitly or implicitly) was labeled as effective and essential in protecting non-Native defendants.

Lexical features for "otherness": The theme of the tribal provision as a threat to the constitutional rights of non-Native defendants was very evident in the use of lexical 
features. The New York Times article, "Measure to protect women stuck on tribal land issue" (Weisman, 11 February, 2013), describes opponents of the provision as inheriting an "unwillingness to trust Native Americans to uphold the Constitution." This article also uses lexical features to describe the provision as "extremely dangerous," signifying the provision as a threat. Tribal courts were described in this article as "not equipped" to handle cases involving non-Native defendants, and fears were expressed that the courts would "deprive defendants of their constitutional rights." This also implies that the current legal process in place is equipped or capable of handling domestic violence cases, thus labeling tribal courts as being "outside" of the current system.

Another mainstream article, "VAWA hits snag in House," published in Roll Call (Strong, 16 May 2012) stated that "the bill," or VAWA, "breaks with 200 years of American legal tradition that tribes cannot exercise criminal jurisdiction over nonIndians." The specific labels of "American" and "tradition" not only explicitly state that the legislation "breaks away" from a common practice, but states that tribal courts (the implicit claim) are not traditionally American, which conveys "otherness" and defines tribal courts as being "outside" of an American system. The fact that tribal courts also "cannot exercise criminal jurisdiction over non-Indians" also explicitly states that the tradition has also been to prevent tribal courts from exercising legal practices, further defining tribal courts as belonging on the outside of the legal system. The implication presented from the statement implies that tribal courts are not as credible as the "traditional" federal court system that has handled cases involving non-Native individuals. 
One of the more direct quotes which indicate otherness was a quote from Representative Tom Cole of Oklahoma (Weisman, 11 February, 2013). While referring to the belief that Cole's colleagues in Congress hold about tribal courts, he stated that some of these individuals "fear Indians are going to take out 500 years of mistreatment" on non-Native individuals with the use of the tribal provision. This statement not only depicts the "fear" that tribes and tribal courts will abuse the system, but conveys a specific motive that they will abuse the system because of the "500 years of mistreatment," or oppression that tribes have faced through the federal government. This fear behind an (assumed) underlying motive shows that tribes and tribal courts are depicted as both opposed to the current system but also deviant, mischievous, or underhanded in nature, thus posing a threat to non-Native individuals.

Specific examples of dialogues and associating issues: Two specific articles, both published in the Grand Forks Herald (Haga, 29 March, 2013; Haga, 30 March, 2013), were published after the passing of the legislation. These articles referenced a specific account between Representative Kevin Cramer and tribal members in the context of a meeting with the North Dakota Council. This context specifically describes an exchange between Cramer and Melissa Merrick (domestic violence survivor and member of the Spirit Lake Nation). The two articles emphasize Cramer's discomfort of passing VAWA with the tribal provision as well as additional remarks about tribal courts themselves. Most of the information from the articles are also based on the account that Merrick had written on a website. 
Cramer is reported as saying he would not feel "safe" on reservations with the new tribal provision. According to Merrick's account posted online, Cramer stated that VAWA and the tribal provision "threatened due process rights of non-Indians" and that the provision was "unconstitutional." Cramer is also reported as stating that "tribal governments are dysfunctional." Cramer himself (in his own words) did deny using the word "dysfunctional," but he did state that he believed VAWA contained "constitutional flaws that are likely to bring court challenges" (Haga, 29 March, 2013). But despite the fact that Cramer denies using the specific term "dysfunctional," he still implies that tribal courts themselves contain "flaws" or problems that ultimately challenge the Constitution and constitutional rights. This claim states that tribal courts are not only outside of constitutional values, but also pose a threat to these values because of their inherent "flaws." Cramer himself also stated that tribes were "overloaded" with legal cases, implying that tribes are not capable of handling additional domestic violence cases involving non-Native individuals (Haga, 29 March, 2013). This claim further defines tribal courts as dissimilar to federal courts as well as incapable or inferior to federal court systems.

In summary, the "Indian as other" frame used in the news coverage of VAWA sent a clear message or depiction that tribes and tribal court systems are not only outside of federal court regulations (which challenges the credibility or capabilities of tribes), but that they present a threat to non-Native individuals because of the differences in these two types of legal systems. This frame was only seen in four of the 35 articles (11\%) in mainstream coverage, and was not seen at all in Native American press or tribal press 
coverage. But one of the emergent frames that was discovered from the news coverage of the legislation-the tribal sovereignty frame-can be thought to directly challenge the "Indian as other" frame. This frame gives a different depiction of the tribal court systems as well as a different perspective about the tribal court provision in the legislation.

\section{The Tribal Sovereignty Frame: An Emergent Frame}

Common themes presented under the tribal sovereignty frame include information that focused on the capabilities of tribes to exercise the rights given through VAWA's tribal provision, and the ability of tribes to govern themselves while protecting their citizens through the exercise of this provision. Some articles that contained the tribal sovereignty frame also emphasized the ability of $V A W A$ 's tribal provision to expand the sovereign rights of tribes in general; information which detailed the expansion of tribal sovereignty claimed that the provision is needed in order for tribes to assert and establish their recognition as government entities. The "tribal sovereignty frame" directly challenges the "Indian as other" frame, which questions the tribes' ability to handle intimate partner violence cases.

Identification and use of the tribal sovereignty frame: The tribal sovereignty frame was seen in all three genres of press media. The original research question and hypotheses did not specifically address the frequency of this emergent frame, but the frame appeared to be slightly more frequently used in Native American press and tribal press combined in comparison to mainstream press. Overall, the tribal sovereignty frame was used in $23 \%$ (eight out of 35 ) of the mainstream outlet articles, and was used in $38 \%$ 
(ten out of 26) of the Native American and tribal outlet articles combined. The tribal sovereignty frame was also closely used with the second emergent frame, the women's rights frame.

Lexical features for tribal sovereignty: Some of the common lexical features that identified the tribal sovereignty frame include words such as "authority," "sovereignty," and "self-determination," and the use of the word "sovereignty" was most commonly seen in news content. One tribal press article published in Au-Authm Action News (20 February, 2014) described the legislation as "a momentous step forward for tribal sovereignty and self-determination," and that the tribal provision in VAWA will "strengthen tribal capacity," or tribal ability, to prosecute offenders of domestic violence. An article published in the Native American press outlet The Circle, News from an American Indian Perspective (Wilson, April 2013) stated that the act "gives tribes more sovereignty," and the article also uses a metaphor to specifically state that tribes are now "armed" with an "arsenal of sovereignty" to address domestic violence cases involving non-Native defendants. The use of this metaphor signifies that the tribal provision or sovereign rights themselves are weapons or tools in addressing domestic violence rates.

Another article published in Au-Authm Action News (18 October, 2012) stated that Indian nations in the United States are "the only governments in America without jurisdiction" to prosecute domestic violence cases, and that the country should consider "restoring ... tribal authority to enforce tribal law over all perpetrators" of intimate partner violence. This statement emphasizes the need for the U.S. government to expand 
powers to tribes and their court systems in order to pursue "all perpetrators" of intimate partner violence, which includes non-Native individuals.

Coverage which addressed the "Alaska exemption" also used the tribal sovereignty frame to describe the rights of Alaska Native tribes to expand sovereign powers. One Seminole Tribune article (29 March, 2013) addressed the issue with the "Alaska exemption" in the legislation, and stated that one of the reasons for "increased violence in Alaska" is the lack of jurisdictional power of tribes as well as the lack of tribal court systems in Alaska Native villages. The article also stated that because of these reasons, the tribal court provision should also apply to Alaska Native villages in order to address high domestic violence rates; this signifies the need for Alaska Natives to also exercise sovereignty to protect tribal members. Another article published in the mainstream outlet The Washington Post described the repeal of the "Alaska exemption" from VAWA removed by Congress in December 2014. The article described the exemption as an "error" and stated Alaska Native tribes needed to be "empowered" in order to protect Alaska Native citizens; the article claimed that this "empowerment" will result from the revocation of the "Alaska exemption" and access to the tribal provision.

In-group/Out-group language: One feature of the tribal sovereignty frame is the presentation of the federal courts as inadequate along with the presentation of tribal courts as more effective. One mainstream press editorial published in the Turtle Mountain Star (25 February, 2013), was written by Winona LaDuke - Native American activist and scholar - and described how federal courts have failed to prosecute a number of domestic violence cases involving Native American plaintiffs. The editorial titled 
"Violence Against Women Act: Why Native women matter" explained how this flaw in the federal court system, or the failure to prosecute domestic violence cases, "concerns tribes deeply," and the solution to this problem is further support of "the infrastructure for justice in Native America," or support for tribes and their court systems.

While the LaDuke article explicitly identifies a specific flaw in the federal court system, two additional articles use implicit meaning and in-group language to signify the competence of tribal courts and the incompetence of federal courts. The article "Indian Country leaders, advocates celebrate passage of $V A W A$ " published in the Native American Times (Krehbiel-Burton, 8 March, 2013) presented one source who stated that the Citizen Potawatomi Nation specifically has "an outstanding court system" and a “better understanding of our citizens' needs". Although the federal court system is not explicitly mentioned in this statement, the phrase "better understanding" does imply that the tribe's understanding of its citizens is superior in comparison to the federal court system's understanding of tribal members' legal needs. The statement also uses the phrase "our citizens' needs" to signify the use of in-group language (the tribal government) in comparison to the federal government. One article published in the Confederated Umatilla Journal (Arnold, January 2014), described the benefits of VAWA as well as the Tribal Law and Order Act, and stated that VAWA will provide "a more effective deterrent to crime in Indian Country". This statement also implies that the previous system of federal court prosecution was not as "effective" in addressing these cases. 
The tribal sovereignty frame highlighted the strengths of tribal courts and their ability to prosecute non-Native defendants under the legislation's tribal provision. But one key aspect or theme emphasized in the tribal sovereignty frame is the ability for tribes to protect their citizens, and this theme also closely links to the second emergent frame of this analysis. The women's rights frame specifically addresses domestic violence survivors in relation to the Violence Against Women Act.

\section{The Women's Rights Frame: An Emergent Frame}

Articles that contained the women's rights frame emphasized themes related to the importance of women survivors of domestic violence and their right to be protected from violent offenders. The frame emphasized the right of women victims to exercise their civil liberties in court to ensure protection from perpetrators, and described how $V A W A$ 's reauthorization would give women victims the resources to exercise their right to safety and legal recourse. These articles used information about intimate partner violence as a justification to why the legislation should be passed in order to give greater protections to Native American women on reservations.

Some articles also addressed the previous benefits of the original Violence Against Women Act of 1994, and these benefits include the dissemination of grant money to support women's shelters and the reduction in intimate partner violence rates nationally. Articles which conveyed this frame either addressed Native American women specifically, or addressed all women affected by domestic violence; the articles which include all women affected by violence also specified Native women as the most 
vulnerable racial group affected by violence. The women's rights frame included the use of statistics on violence against women; these statistics were used to show the disproportionate rates of violence against women and as a justification of why the legislation (with the inclusion of the tribal provision) was needed to protect women.

Frequency of the women's rights frame: Similar to the tribal sovereignty frame, the use of the women's rights frame also appeared to be used more frequently in Native American and tribal press coverage compared to mainstream press coverage. Overall, the women's rights frame (with the inclusion of use with the conflict frame and tribal sovereignty frame) was used in $23 \%$ (eight out of 35) of mainstream articles and $46 \%$ (12 out of 26 articles) of Native American and tribal press articles combined. One noticeable feature about the use of the women's rights frame in mainstream press coverage is that more than half of the mainstream editorial articles (four out of the seven articles) also used the women's rights frame. This feature of journalistic practice will be further discussed later in this report.

Another noticeable feature of this frame is that some articles which contained the women's rights frame also contained either the tribal sovereignty frame or the conflict frame. Identification of the women's rights frame, as well as the justification of the frame's use in conjunction with the additional frames, will be discussed in terms of how this emergent frame contributed to the news discourse of the Violence Against Women Act. 
The women's rights frame when used alone: When the women's rights frame was used alone in the articles, one common theme associated with this usage was information which addressed race specifically, along with the historical context of the treatment of Native American women in the United States. One article published in the local mainstream outlet Sunday News (Powers, 29 July, 2012) stated that women of color experience racism and sexism in the country, and have failed to be helped in a court of law. This information was presented to justify why VAWA should be passed in order to protect these individuals. Another article published in the Native American Times titled "Senate votes to renew VAWA" (Krehbiel-Burton, 22 February, 2013) stated that Native American women specifically have a "long history of being mistreated, captured, raped, violated, and murdered." This statement introduces the historical context of violence against Native American women in the country. The article also stated that "the lack of equal protection is unwise and unjust," which implies that Native American women receive unequal protections specifically in comparison to other groups of people (or nonNative individuals).

An article published in the tribal press outlet the Cherokee Phoenix titled "VAWA passes Senate, heads to House" (March, 2013) also addressed the disproportionate rates of violence against Native American women specifically. The article quoted U.S. Attorney General Eric Holder, who stated that VAWA will "close a significant jurisdictional gap that has left too many Native American women, precisely because they are Native American, exposed to violence for far too long." This phrase signifies that Native women, women of this specific racial group, are left unprotected because of who 
they are as individuals, and the underlying causes for violence against Native women-the failures to prosecute non-Native men on reservations-is associated with this racial/gendered category. This information emphasized the need for Native American women specifically to receive better government and legal protections from perpetrators of violence.

Women's rights frame used with the tribal sovereignty frame: Based on the article analysis, the purpose of using both the women's rights frame and the tribal sovereignty frame is to explain how the tribal provision and tribal sovereignty will help Native American women exercise legal rights and receive safety from perpetrators. One article published in the Native American press outlet Sho-Ban News (Edmo-Suppah, 7 November, 2013) stated that women should be "empowered to heal" and that tribal governments "should be essential parts" in reducing domestic violence rates. This states that the tribal governments and their court systems should be necessary elements in allowing Native women to overcome domestic violence abuse.

One Au-Authm Action News article (18 October, 2012) mentioned how Congress should "remove legal barriers" in the law that "discriminate against Native women", which claims that the "legal barriers" would be removed with the passing of VAWA and the tribal provision. Another article from the same outlet (7 March, 2013) published after the passing of VAWA stated that the legislation will provide "much needed tools for tribal justice systems" to "effectively" protect Native American women, and that these women are "now safer" under the tribal provision. This passage emphasizes the need of tribal 
courts to prosecute non-Native men for crimes against Native women in order to protect these women from violence.

One specific case of the use of both frames involves the interpretation of a Native American proverb in two specific articles published before VAWA's passing. The two articles were editorial pieces written by Winona LaDuke and Louise Erdrich (another Native American scholar). The LaDuke editorial (25 February, 2013) was referenced earlier in the tribal sovereignty frame section; the Erdrich editorial (27 February, 2013) was published in the New York Times and titled "Rape on the reservation."

These two Native American women include a Cheyenne proverb (or lexical feature) in their pieces, which states that, "a nation is not conquered until the hearts of its women are on the ground." In reference to the Violence Against Women Act, this proverb was used to explain how the vulnerability of women also impacts tribal nations, and that the tribes' ability to protect its citizens (through the exercise of tribal sovereignty) is important for the survival of both the nation and its women. Erdrich specifically summarized the proverb by stating "if our hearts are on the ground, our country has failed us all. If we are safe, our country is safer." Although Erdrich does not specify what is meant by "country," the term could specifically refer to tribal nations, the United States, or both. Erdrich also uses the in-group term "we" (signifying Native American women) to describe how protecting Native women will keep both these individuals safe as well as an "entire country safer." With the use of the Cheyenne proverb, both articles described the need for tribal governments to exercise their sovereignty with VAWA's tribal provision in order to better protect women on reservations. 
Women's rights frame used with the conflict frame: The women's rights frame used in conjunction with the conflict frame was only seen in tribal press articles, and this occurrence was also the only time where the conflict frame was used in tribal press coverage overall. Based on the article analysis, the use of these two frames emphasized the conflict between the two political parties (Democrats and Republicans), but used this conflict to specifically show how these disputes deterred or interfered with granting legal protections to Native American women. The articles that used both frames emphasized positive attributes of the tribal provision's benefit to Native American women, while also emphasizing the negative attributes of Congress and the process of reauthorizing the bill.

One of the articles that presented both frames, an $A P$ story, was the Cherokee Phoenix article "VAWA bill signed into law" (April 2013). The author of this article stated that the legislation addressed "crimes against women and some men," which claims that VAWA is more of a women's issue than an issue that concerns men. The article further described VAWA's passing as a "victory" for women nationwide. The article stated that the legislation "set the standard for how to protect women from domestic abuse," then stated that the legislation is credited with reducing domestic violence rates by two-thirds.

The author continued to introduce the conflict frame later on in the article and describes the process of passing VAWA as involving "partisan bickering." The article also stated that President Obama's attempts to renew the legislation "failed in 2012 after they became entangled in gender politics and the presidential campaign." This sentence 
presents two verbs (failed, entangled) and a passive transformation with the use of the past-tense phrase "became entangled"; only one subject, the pseudo-subject of "the President's attempts," is given in the statement, along with two vague circumstances (gender politics and the presidential campaign). This passage does not attribute a specific agent as causing the rejection of VAWA in Congress, but the two presented circumstances imply that conflict involving politicians (who typically contribute to these circumstances) deterred the process of passing the legislation.

The author also stated that Republicans specifically "saw the move to load a popular bill with controversial elements as a provocation"- one of the controversial elements being the tribal provision. In this statement, the legislation is labeled as "a popular bill," but the tribal provision specifically is also perceived (by Republicans) "as a provocation," or a challenge to the Republican party. This article gives an example of how the use of the conflict frame in tribal press coverage was presented in order to emphasize the need to protect women from violence as well as to highlight how politics in Congress threatened women's rights overall.

Specific statistics about violence against women: Information provided in articles that contained the women's rights frame also used specific statistics to support the claim that women, and specifically Native American women, need special protection from perpetrators of violence. The statistics in these articles (as well as additional articles which did not use the frame) was information published in specific government documents and research reports. 
The most commonly-cited statistics were from a Justice Department report published in 2000 (see Tjaden \& Thoennes, 2000). One of the statistics from this report is "one in three Native American/Alaska Native women (or 34\%) will be raped in her lifetime." Another figure from this report stated that "Native American/Alaska Native women are 2.5 times more likely to be sexually assaulted than any other women in the United States (or women of other racial groups)." One statistic addressed intimate partner violence specifically, and stated that " $39 \%$ of Native American/Alaska Native women are subject to violence by an intimate partner."

Other statistics include information from the Indian Law Resource Center and the Government Accountability Office. The Indian Law Resource Center statistic commonly used in the news articles stated that " $88 \%$ of sexual assault crimes against Native women are committed by non-Native perpetrators" (18 October, 2012; Krehbiel-Burton, 22 February, 2013). The 2010 report from the Government Accountability Office stated that "federal prosecutors declined to pursue half (52\%) of violent crimes committed in Indian Country, as well as two-thirds (67\%) of sexual abuse cases committed Indian Country, between 2005 and 2009” (1 March, 2013; 29 March, 2013).

One important feature of the statistics presented in the articles is that some of the articles specifically cite the original source of these statistics, while some only cite person sources who reference these statistics without attributing the information to government

\footnotetext{
${ }^{5}$ The statistics from the Tjaden and Thoennes (2000) report are slightly different from the CDC report described earlier in the literature review. Tjaden and Thoennes (2000) state that $39 \%$ of Native American/Alaska Native women are subject to intimate partner violence, while Black et al. (2011) state that $46 \%$ of Native American/Alaska Native women are subject to intimate partner violence. This comparison presents a noticeable increase in the rate of intimate partner violence against Native American women within a ten-year time span.
} 
documents or organizations. The next section will explore source use specifically in terms of the types of person sources used to convey the general information presented in news coverage. Examining source use may also explain how specific sources contributed to the creation of media frames as well as the news discourse about the Violence Against Women Act and Native American communities.

\section{Source Use in News Coverage}

The second research question addressed the types of sources used in the coverage of the Violence Against Women Act. The types of person sources in the news coverage of all three genres of media were grouped into specific occupational categories. These occupational categories were created based on similarities of the representative organizations of each person source, and four specific occupational categories were used in this analysis based on how frequently these types of sources belonging to these categories were used in news coverage. The next section will describe the description of the occupational categories as well as the frequency of the sources from these categories seen in all three press genres. This analysis also explores how these types of sources may had contributed to the news narratives presented in the coverage of the legislation.

\section{Occupational Categories}

Federal and state government officials: The most common types of sources seen in the news coverage were individuals who were classified under the "federal or state government officials" category. These included members of Congress (from the Senate and the House of Representatives), the President of the United States and 
members of his Cabinet, and individuals who serve specific federal or government offices (such as the Bureau of Indian Affairs). This category also included legal attorneys who specifically work for the federal government or state government (such as U.S. and state attorney generals). The category of "federal and state" government officials was also used to distinguish between these government entities and tribal governments.

Tribal government officials: Individuals who were classified as "tribal government officials" were the second-most frequently used types of sources in the news coverage. These individuals largely consisted of tribal council members of specific nations described in the articles as "principal chief," "president," "councilman," "councilwoman," or "council representative" of a specific tribe or nation.

Legal representatives employed by tribal governments (members of tribal court systems; attorneys hired by the tribes) were also included under the "tribal government officials" category. Examples of language used to describe the occupational titles of these individuals include labels such as "tribal prosecutor," "chief prosecutor," and "attorney," and these labels were followed by the name of the associating tribe.

Some specific sources also included under this category were sources who worked under social service offices operated by specific tribes and nations. Examples include one source labeled as the "Chairman of the Pascua Yaqui Tribes' Public Safety Committee;" another source was described as the "Executive Director of the Cherokee Nation Office of the Attorney General Domestic Violence Service.”

Social service agencies and women's shelters: Representatives from these organizations were the third most frequently used types of sources in the news coverage. 
These representatives and their organizations provide social services for domestic violence and sexual assault survivors as well as services for children and families. Specific shelters (also called women's shelters) also provide housing for survivors attempting to escape their abusers and abusive environments. Organizations under this occupational category are non-profit organizations, and some of these agencies also receive assistance from specific tribes. Social service agencies included the Domestic Violence Intervention Services Inc. (Tulsa, Oklahoma) and the National Indigenous Women's Resource Center (Lame Deer, Montana). shelters (or women's shelters) included Hearts of Hope (Belcourt, North Dakota) and the Pretty Bird Woman House (McLaughlin, South Dakota).

Native American organizations: Representatives from specific Native American organizations were the fourth most frequently used sources seen in the news coverage. This category included representatives who work for organizations that serve Native American / Alaska Native communities in the United States. These were largely nonprofit organizations that provide legal assistance and resources to these communities as well as lobby and advocate legal rights on behalf of tribal communities. Representatives include members from the National Congress of American Indians (NCAI), the Indian Law Resource Center, and the Tribal Law and Policy Institute.

\section{Source Frequency by Media Genres}

Federal and state government officials (also known as types of official sources), have been known to be commonly used in mainstream news coverage based on previous literature. But little is known about their presence in Native American press or tribal 
press. This analysis shows that all three genres of media heavily relied on the use of federal and state government officials in the news coverage of VAWA. Out of the total number of articles $(\mathrm{N}=61), 61 \%$ of the articles (37 out of the 61 articles total) used at least one federal or state government official to contribute to the news discourse. In the mainstream press outlets, $57 \%$ of these articles (20 out of the 35 articles) used at least one federal or state representative to contribute to the news discourse. In Native American press and tribal press combined, $65 \%$ of these articles (17 out of the 26 articles) used at least one federal or state government official in the news discourse.

Although federal and state government officials were prevalently used in all three media genres, the use of tribal government officials shows a noticeable difference between the genres. While mainstream press outlets used at least one tribal government official in $23 \%$ (eight out of the 35 articles), Native American press and tribal press combined used at least one tribal government official in $46 \%$ of these articles (12 of the 26 articles) - or double the amount of mainstream press. The use of representatives from Native American organizations was also noticeable between the media genres. While mainstream press outlets contained at least one representative in $9 \%$ of the articles (three of the 35 articles), Native American press and tribal press combined used at least one representative in $23 \%$ of the articles (six of the 26 articles). Sources from social service agencies and shelters were more evenly distributed amongst the media genres; mainstream press contained at least one representative in $34 \%$ of the articles (12 of the 35 articles), and Native American and tribal press contained at least one representative in $30 \%$ of the articles (eight of the 26 articles). 
Sources from all four occupational categories contributed to information about VAWA and Native communities, but these sources can also contribute to specific frames conveyed in news coverage. Source use in these news articles may help explain how the different media genres were able to convey the literature and emergent frames. But additional journalistic practices, such as source attribution techniques and the use of editorials, may also explain how the media genres were able to present the frames in the news coverage of VAWA.

\section{Source Contribution to the Media Frames and News Discourse}

One explanation as to the frequency of federal and state government officials is the use of source attribution analyzed in the article coverage. A common practice of all three media genres was to use statements that were originally presented in either formal written statements, or to use quotes stated in previous moments in time. Written statements from federal and state government sources include print or online documents, and these statements are typically given to journalists in the form of press releases. Common contexts involving previous time periods include quotes originally made in Congressional sessions and meetings, usually by members in Congress. Other contexts seen in this analysis included officials who made statements during visits to reservations (such as statements made by President Obama and U.S. Attorney General Eric Holder during previous visits to reservations).

Based on the use of these attribution forms, federal and state government officials were more likely to be quoted from written statements or previous time periods compared 
to the other sources. This trend appears to contribute to the large amount of federal and state representatives seen in the news coverage of $V A W A$. Tribal government officials were also stated in these types of contexts, but were more likely to be directly interviewed and quoted by the article authors themselves. Federal and state government officials not only seemed to be heavily used in the coverage of the legislation, but based on the frame identification methods of the conflict frame, they also appear to largely contribute to conflict in the news discourse. Federal and state government officials were more likely to question the capabilities of tribal courts to handle cases involving nonNative defendants, and more involved in cases of dispute amongst party lines over the passing of $V A W A$ with the tribal provision.

Federal and state government officials were also used in articles which conveyed the "Indian as other" frame and were used to describe tribal court systems as a threat to non-Native defendants. Tribal government officials as well as representatives from Native American organizations and shelter/service agencies were seen in these articles, but these sources did not appear to support the assertion that tribal courts threaten due process. These three types of sources were used to either provide general information about $V A W A$ or domestic violence, or were used in relation to the conflict frame (presented in all four articles) to contribute to the discussion about VAWA.

Federal and state government officials appear to dominate the media discourse surrounding both conflict and "otherness," but the emergent frames appear to introduce more tribal government officials and social service/shelter perspectives in news coverage. Tribal government and Native American representatives appeared to contribute to more 
discussions about the importance of tribal nations to exercise their sovereignty and protect their citizens. Tribal government officials specifically also heavily contributed to perspectives of women's rights and protecting Native American women on reservations.

Shelter/social service agents appeared to contribute to both providing general information about VAWA as well as emphasizing the importance of reauthorizing the legislation to continue to help survivors of domestic violence. Mainstream press did introduce the women's rights frame in news coverage, but the contribution to this frame also came from the use of editorials. This journalistic practice may explain how the influence of opinion pieces (written by news outlet staff or outside writers) contributes more perspectives which support the passing of the legislation. Without the presence of these editorials, some mainstream outlets may not have presented or emphasized the importance of VAWA to Native women and Native communities.

The types of sources that each genre of media use in their news coverage does appear to affect which frames are conveyed in the coverage and which narratives their audiences will receive. But the use of other media practices, such as borrowed information from statements or websites and editorial contributions, can also affect how an issue is covered and which types of sources have the ability to contribute to the news discourse. Since the use of public statements was largely attributed to government sources (mainly federal and state sources), this appears to affect how these sources were able to contribute their opinions about VAWA in the news coverage. The editorial pieces, specifically in mainstream press, also appear to give more perspectives on women's rights and domestic violence. These types of journalistic practices help explain how 
different narratives were introduced in the news coverage of the Violence Against Women Act as well as which media genres were more likely to introduce or emphasize these narratives in the news coverage. 


\section{Chapter 8: Discussion}

The role of the media has traditionally been thought to serve the public interest by providing information on the topical news issues of the day. This analysis examined the role that different genres of media played in the coverage of a specific social issue which affects specific groups in society classified by race, nation, and gender. Mainstream media have an established reputation of misrepresenting racial and ethnic groups, including Native Americans, in media coverage, as well as introducing conflict in the coverage of public policy issues. This analysis explored whether mainstream press still continued these dialogues and narratives in the news coverage of VAWA 2013, and whether Native American press or tribal press introduced additional narratives in the news discourse.

\section{Media Frames, News Narratives, and Audience Perception}

In terms of how the media frames in this analysis contributed to news narratives about VAWA and Native communities, the noticeable difference between mainstream press in comparison with Native American and tribal press is the presence of conflict and "otherness" in the news discourse. Based on the findings of this report, mainstream press still appears to produce narratives of conflict in news reports as well as depictions of "otherness" in relation to Native American cultures and systems.

Native American press and tribal press, on the other hand, appear to provide limited coverage on conflict and do not depict Native American groups in relation to "otherness". Since the media agendas of these two genres is to include Native American 
groups as main subjects of news discourse, these outlets also abandon the common "otherness" depictions (typically used in mainstream media) in order to serve and better represent their niche audiences. Since these narratives are not present or emphasized in Native American or tribal press coverage, the audiences of these news outlets may only receive messages which state the benefits of the legislation on tribes and Native American women. Based on the prevalence of the literature-based frames, audiences which typically receive their news from mainstream press may receive more messages pertaining to the controversial aspects of the legislation. These audiences may also develop the perception that tribal governments and tribal court systems are not equipped to handle domestic violence cases involving non-Native individuals.

Despite the fact that these literature-based frames continue to produce narratives about Native American communities in news discourse, the emergent frames were used to highlight the capability of tribes to handle intimate partner violence case and the importance of protecting Native women on reservations. These emergent frames may have contributed to the perception of policy makers in supporting the legislation, thus allowing VAWA 2013 to be passed and implemented. The use of the additional emergent frames in the mainstream coverage may support the idea that mainstream media are introducing multiple narratives in the discussion of public policy issues such as VAWA. But despite the fact that the mainstream coverage did include the emergent frames, Native American press and tribal press placed greater emphasis on producing perspectives of tribal sovereignty and women's rights in news discourse.

\section{Addressing Violence and Indigenous Communities through News Narratives}


The emergent frames as well as Native American and tribal press outlets appear to play a role in promoting ideologies associated with tribal sovereignty and Indigenous perspectives of intimate partner violence. From an Indigenous perspective, violence in Indigenous communities is viewed as a systemic issue related to policy implementation. The narratives presented in the emergent frames suggest that this issue should be addressed or solved with the systemic solution of implementing a policy - passing VAWA 2013 with the tribal provision. The narratives produced from the tribal sovereignty frame emphasized the importance of addressing intimate partner violence as a systemic issue and allowing tribal courts to be able to protect citizens who reside on reservations. Narratives from the women's rights frame also explain that intimate partner violence should be addressed as a systemic issue and have a systemic solution in order to protect Native American women, who are the most vulnerable demographic group affected by violence.

These frames and press genres also challenge ideologies associated with colonization, such as Christian ideology related to the suppression of women and ideologies of deviance and inferiority. Mainstream media have traditionally covered intimate partner violence as an issue related to individual faults instead of systemic factors, and coverage of Indigenous communities have also involved depictions of Native cultures as deviant or inferior to Anglo-European culture. Depictions of conflict and otherness in the coverage of $V A W A$ was used to distract from the narratives of systemic problems that affect reservation communities in the United States. The conflict frame emphasized disputes about $V A W A$, and instead of addressing problems with the federal 
court system, the "Indian as other" frame emphasized the faults of tribes and tribal courts. These two frames were also more heavily used in mainstream press coverage.

But these ideologies were challenged with messages that assert tribal sovereignty and introduced historical and racial context to the coverage of domestic violence in Native American communities. Since Native American and tribal press outlets appear to introduce more of the emergent frames in the news coverage, these specific genres also place more emphasis on these counter-narratives. One explanation to the use of the emergent frames in the press genres is media ownership. The media owners of Native American and tribal press outlets may have a better understanding of the historical factors that contribute to intimate partner violence in Native communities, and this understanding may contribute to explaining the importance of protecting Native women with the expansion of tribal sovereignty.

\section{Social Power and Media Genres}

Structural factors, such as media ownership and media agendas, have been typically thought to contribute to frame creation. Interest groups are also known to exercise (or abuse) social power by influencing media practitioners to promote group ideologies through news coverage. As mentioned earlier in the theoretical framework section, framing scholars who work under a critical paradigm (consisting of multiple critical theories) can analyze social power by the inclusion of information provided by certain interest groups as well as the exclusion of information resulting from the suppression of other interest groups. 
Sources traditionally labeled as official sources (such as federal and state government sources) have been known to dominate news discourse in mainstream coverage. This access to news discourse may be the result of journalists maintaining ongoing relationships with familiar public officials as well as the ability of these officials to contribute to general news items that affect the entire country. On the other hand, journalists who work for mainstream outlets may also be less familiar with tribal government officials, especially since these officials may be perceived as contributing to news discourse which only affects Native American communities. Because news items related to Native Americans are less frequently covered in mainstream press, sources who represent Native populations may not be cited as frequently compared to general policy makers on the federal or state government level. In cases of news reports that specifically address specialized populations, media such as Native American media and tribal media may have a better understanding of news issues that affect these populations and have better relationships with specific sources representative of these populations.

Source use and media frames introduced through Native American press and tribal press may explain the role these two genres play in allowing Native American groups to gain more access to news coverage and present alternative perspectives in news discourse. Critical race theory specifically states that marginalized groups can promote their ideologies and exercise social power through the use of counter-narratives or counter-dialogues presented in news coverage. One example of this use of counternarrative was evident in the presentation of the tribal sovereignty frame, an emergent media frame that was more frequently used in Native American press and tribal press and 
that directly challenged the "Indian as other" frame (used in mainstream press only). This use of counter-narrative can also be perceived as the exercise of social power by tribal governments, and tribal critical race theory scholars working from a communications perspective may also call this the enactment or exercise of sovereignty.

Tribal critical race theory states that power is characterized by the ability of tribes to define or represent themselves and their traditions, thus asserting their sovereignty. The introduction of specific information provided by the emergent frames (historical contexts related to violence against Indigenous women) and sources who contributed to these frames (tribal government representatives) also appear to contribute to the representation of tribes and their traditions in the coverage of $V A W A$. This contribution can also be perceived as asserting the sovereignty of tribes (especially through the tribal sovereignty frame) in the news discourse that directly affects tribal communities in the United States.

Despite the fact that federal and state government sources largely dominated the coverage of the legislation, tribal government officials and representatives from Native American organizations were used more frequently in Native American press and tribal press specifically. This contribution appears to give these sources more access to news discourse though the use of these two media genres. Since power is evident in terms of how sources dominate or contribute to news discourse, the contribution of these types of occupational sources through Native American and tribal press may explain how these sources and representative constituent populations are able to gain or exercise more social power through these two media genres. 


\section{Limitations and Contributions to the Research}

Narratives of conflict and otherness still seem to exist in news discourse produced by mainstream press, while Native American press and tribal press place more emphasis on producing perspectives of tribal sovereignty and women's rights in news discourse. From a critical framing perspective, these specialized media platforms may also be used to allow certain interest groups not typically represented in mainstream coverage to be able to contribute their perspectives to the news discourse. Although this research is able to give insight into a particular social issue which affects Native Americans in the country, this research also contains limitations in the analysis of Native American representations in the media.

One of the limitations to this research involves the limited academic study of Native American media and tribal media. Some conceptualizations and definitions of these two genres of media are available, but there is also limited research as to what types of media frames are present in the news coverage of these media genres, as well as how the media agendas of these genres affect news discourse. Another issue with this limited inquiry is the lack of comparison between Native American media and tribal media. In terms of structural factors (such as media ownership) that may affect the news coverage of these two genres, Daniels (2006) does state that Native American media are known to cover more controversial issues about tribal governments because of the lack of tribal government ownership and control over these media outlets. Ownership control may have varying effects on news discourse of a controversial issue, and may influence media frames presented in these media genres. 
Another limitation to this research is that other forms and genres of media were also not included in this analysis. These media types include different formats such as radio, TV broadcast, and online only formats of media outlets. Specific Native American media outlets are included in these various formats, such as the online news feed indianz.com and the online newsletter Indian Country Today - this publication discontinued its print circulation in 2013. These different Native American formats of media were left out of the analysis for the purposes of examining outlets across all genres with similar audience access to each media outlet (or each outlet containing specific print circulations in physical locations in the country).

Other genres of media were also not included in the analysis, such as other ethnic media outlets or other alternative media genres (e.g.; Aljazeera, Democracy Now). These different genres of media were left out for the purposes of examining outlets whose media agendas relate to serving Native communities specifically. Because of this limitation, this research can only give insight into press outlet coverage (one aspect of "media" as a whole) and frames presented in press coverage only.

Despite these limitations, this examination of media frames produced in three media genres provides a better understanding of the functions of these genres, as well as the possible influence of social power and source use in the creation of media frames. This research is able to explain how Native American populations are represented in news discourse across varying media genres, as well as the specific perspectives and news narratives that these communities are able to contribute in the discussion of a relatable topical issue. 
Since this research was a case study analysis and analyzed one social issue and time frame, this also affects the generalizability of research findings to other topical issues related to Native Americans. But this case study presents a comprehensive examination of the news coverage of VAWA 2013 during this particular time period, as well as how the coverage was presented in outlets specifically designed for Native American audiences. This report was also able to explain the conceptualizations of the two literature-based frames through the article analysis and the linguistic structures which contributed to the media frames. The emergent frames identified in this analysis could also be used in future studies to examine other news issues that affect women and Indigenous communities. 


\section{Chapter 9: Conclusion}

The Violence Against Women Act of 2013 was considered a controversial bill passed in Congress, and one of the elements of this controversy involves the ability of tribal governments to exercise due process over non-Native individuals. Yet news discourse about the legislation contained a variety of narratives which called attention to the controversy, but also addressed the importance of the legislation to Native communities and survivors of intimate partner violence. The role of Native American and tribal press outlets did appear to minimize the controversy behind the bill as well as emphasize the right of tribal courts to protect Native American women from intimate partner violence committed on reservations. And although non-Native individuals were depicted as facing a threat of mistreatment from tribal courts, news coverage also largely focused on the rights of Native American women to be protected from harm and their right to prosecute their perpetrators. Since the Violence Against Women Act is an example of one public policy issue that affects Native American communities, other social and political issues should be analyzed in terms of how mainstream, Native American, and tribal media outlets report these issues.

To build on the literature of coverage presented in Native American and tribal media, future research should explore the organizational differences between these two genres and how these differences affect news coverage of specific issues related to Native American communities. Critical scholars should also consider the role that specific interest groups and organizational sources play in frame creation of news coverage. Framing scholars can also build on the conflict frame and the "Indian as other" frame to 
examine how aspects of these frame can be conveyed in other news discourse related to Native American issues. Since more literature exists on the representations of Native Americans in mainstream media, future research should also further address depictions of Native Americans specifically in Native American and tribal press media outlets. These types of depictions and news narratives may vary in comparison to mainstream outlets and give alternative representations of Native Americans in relation to social issues. 


\section{References}

Adams, D. W. (1995). Education for extinction: American Indians and the boarding school experience, 1875-1928. Lawrence, KS: University of Kansas Press.

Black, M.C., Basile, K.C., Breiding, M.J., Smith, S.G., Walters, M.L., Merrick, M.T., Chen, J., \& Stevens, M.R. (2011). The National Intimate Partner and Sexual Violence Survey (NISVS): 2010 Summary Report. National Center for Injury Prevention and Control, Centers for Disease Control and Prevention. Retrieve from http://www.cdc.gov/violenceprevention/pdf/nisvs_report2010-a.pdf.

Brayboy, B. M. J. (2005). Toward a tribal critical race theory in education. The Urban Review, 37(5), 425-446

Burnette, C. (2015). Historical oppression and intimate partner violence experienced by Indigenous women in the United States: Understanding connections. Social Service Review, 89(3), 531-563.

Carey, J. W. (1997). The communications revolution and the professional communicator. In Munson, E. S. \& Warren, C. A. (Eds.), James Carey, A critical reader (pp. 128-143). U. of Minnesota Press.

Carlyle, K. E., Slater, M. D., \& Chakroff, J. L. (2008). Newspaper coverage of intimate partner violence: Skewing representations of risk. Journal of Communication, $58(1), 168-186$. 
Carlyle, K. E., Savage, M. W., \& Babin, E. A. (2014). News coverage of intimate partner violence: Impact on prosocial responses. Media Psychology, 17(4), 451-471.

Carragee, K. M. \& Roefs, W. (2004). The neglect of power in recent framing research. Journal of Communication, 54(2), 214-233.

Center for Disease Control and Prevention: Division of Violence Prevention (2015). Intimate partner violence. Retrieved from Www.cdc.gov/violenceprevention/intimatepartnerviolence.

Chenault, V. S. (2011). Weaving strength, weaving power: Violence and abuse against Indigenous women. Druham, N.C.: Carolina Academic Press.

Coleman, C. L. \& Dysart, E. V. (2005). Framing of Kennewick Man against the backdrop of a scientific and cultural controversy. Science Communication, 27(3), 3-26.

D’Angelo, P. (2002). News framing as a multiparadigmatic research program: A response to Entman. Journal of Communication, 52(4), 870-888.

Daniels, G. L. (2006). The role of Native American print and online media in the 'era of big stories': A comparative case study of Native American outlets' coverage of the Red Lake shootings. Journalism, 7(3). 321-342.

Deer, S. \& Tatum, M. L. (2003). Tribal efforts to comply with VAWA's Full Faith and Credit requirements: A response to Sandra Schmieder. Tulsa Law Review, 39(2), 403-418. 
Deer, S. (2004). Federal Indian law and violent crime: Native Women and children at the mercy of the State. Social Justice, 31(4), 17-30.

Entman, R. M. (1993). Framing: Towards clarification of a fractured paradigm. Journal of Communication, 43(4), 51-58.

Gamson, W. A., \& Wolfsfeld, G. (1993). Movements and media as interacting systems. The Annals of the American Academy of Political and Social Science, $528,114-125$.

Hall, S. (2015). The whites in their eyes. In G. Dines \& J. M. Humez (Eds.), Gender, Race, and Class in Media: A Critical Reader (4th ed., pp. 104-107). Los Angeles, CA: Sage.

Harlow, S. \& Harp, D. (2013). Alternative media in a digital era: Comparing news and information use among activists in the United States and Latin America. Communication \& Society, 26(4), 25-51.

Harding, R. (2006). Historical representations of Aboriginal people in the Canadian news media. Discourse \& Society, 17(2), 205-235.

Hodges, A. (2015). Ideologies of language and race in U.S. media discourse about the Trayvon Martin shooting. Language in Society, 44(3), 401-423.

Johnson, M. A. (2010). Incorporating self-categorization concepts into ethnic media research. Communication Theory, 20(1) 106-125. 
Kozol, W. (1995). Fracturing domesticity: Media, nationalism, and the question of feminist influence. Signs: Journal of Women in Culture and Society, 20(3), 646667.

Lippmann, W. (1922). The world outside and the pictures in our heads. In Public opinion (pp. 5-19). New York: Harcourt, Brace and Co.

Loew, P., \& Mella, K. (2005). Black ink and the new red power: Native American newspapers and tribal sovereignty. Journalism \& Communication Monographs, 7(3), 99-142.

Luther, C. A., Lepre, C. R., \& Clark, N. (2012). Diversity in US Mass Media. WileyBlackwell.

Matamonasa-Bennet, A. (2015). "A disease of the outside people'”: Native American Men's perceptions of intimate partner violence. Psychology of Women Quarterly, 39(1), 20-36.

Matsaganis, M. D. \& Katz V. S. (2014). How ethnic media producers constitute their communities of practice: An ecological approach. Journalism, 15(7), 926-944.

McConnell-Ginet, S. (2014). Meaning-making and ideologies of gender and sexuality. In S. Ehrlich, M. Meyerhoff, and J. Holmes (Eds.), The handbook of language, gender, and sexuality ( $2^{\text {nd }}$ ed.). John Wiley \& Sons.

McDougal, S. (2014). Research Methods in Africana studies. New York: Peter Lang. 
McQuail, D. (1987). Mass communication theory: An introduction. (2 ${ }^{\text {nd }}$ ed.). London: SAGE.

Meyer-Emerick, N. (2002). Policy makers, practitioners, citizens: Perceptions of the Violence Against Women Act of 1994. Administration \& Society, 33(6), 629-663.

Miller, A. \& Ross, S. D. (2004). They are not us: Framing of American Indians by the Boston Globe. The Howard Journal of Communications, 15(4), 245-259.

Olmstead, A. P. (1998). Words are acts: Critical race theory as a rhetorical construct. Howard Journal of Communication, 9(4), 323-331.

Omi, M. \& Winant, H. (2015). Racial formation in the United States ( $3^{\text {rd }}$ ed.). New York and London: Routledge.

Price, V., Tewksbury, D., \& Powers, E. (1997). Switching trains of thought the impact of news frames on readers' cognitive responses. Communication Research, 24(5), 481-506.

Qureshi, S. \& Trumbly-Lamsam, T. (2008). Transcending the digital divide: A framing analysis of information and communication technologies news in Native American tribal newspapers. Proceedings of the $41^{\text {st }}$ Hawaii International Conference on System Sciences, 1-10.

Richardson, J. E. (2007). An approach from critical discourse analysis. New York: Palgrave. 
Rogers, M. \& Giroux, J. (2012). Domestic violence in American Indian communities: background, culture, and legal issues. In Joe, J. R. \& Gachupin, F. (Eds.), Health and Social Issues of Native American Women (pp. 153-167). Praeger.

Said, E. W. (1989). Representing the colonized: Anthropology's interlocutors. Critical Inquiry, 15(2), 205-225.

Scheufele, D. A. (1999). Framing as a theory of media effects. Journal of Communication, 49(1), 103-122.

Smith, A. (2005). Native American feminism, sovereignty, and social change. Feminist Studies, 31(1), 116-132.

Smith, L.T. (2012). Decolonizing methodologies: Research and indigenous peoples $\left(2^{\text {nd }}\right.$ ed.). New York: Zed Books, Palgrave MacMillan.

Sunstein, C. R. (2001). The daily we: Is the Internet really a blessing for democracy? Boston Review. Retrieved from http://bostonreview.net/cass-sunstein-internetdemocracy-daily-we.

Taylor, C. A. \& Sorenson, S. B. (2005). Community-based norms about intimate partner violence: Putting attributions of fault and responsibility into context. Sex Roles, 53(7), 573-589.

Tjaden, P. G., \& Thoennes, N. (2000). Extent, nature, and consequences of intimate partner violence: Findings from the national violence against women survey (Vol. 181867). Washington, DC: National Institute of Justice. 
The United States Congress (1994). Violent Crime Control and Law Enforcement Act of 1994. H.R. 3355. $103^{\text {rd }}$ Congress, $2^{\text {nd }}$ session, 1994. Retrieved from https://www.govtrack.us/congress/bills/103/hr3355/text.

The United States Congress (2005). Violence Against Women Department of Justice Reauthorization Act of 2005. H.R. 3402. 109 ${ }^{\text {th }}$ Congress, $1^{\text {st }}$ session, 2005. Retrieved from https://www.govtrack.us/congress/bills/109/hr3402/text.

The United States Department of Health and Human Services: Office on Women's Health (2015). Violence against women: Domestic and intimate partner violence. Retrieved from www.womenshealth.gov/violence-against-women/types-ofviolence/domestic-intimate-partner-violence.html\#a.

The United States Department of Justice (2015). Violence Against Women Act (VAWA) Reauthorization 2013. Retrieved from http://www.justice.gov/tribal/violenceagainst-women-act-vawa-reauthorization-2013-0.

Trahant, M. N. (1995). Pictures of our nobler selves: A history of Native American contributions to news media. Freedom Forum First Amendment Center.

Tribal Law and Policy Institute (2015). Text of Indian Civil Rights Act. Retrieved from http://www.tribal-institute.org/lists/icra.htm.

van Dijk, T. A. (1996). Discourse, power, and access. In Text and practices: Readings in critical discourse analysis (pp. 84-104). 
van Dijk, T. A. (2015). Critical discourse analysis. In D. Tannen, H. Hamilton, \& D. Schiffrin (Eds.). The handbook of discourse analysis (2 $2^{\text {nd }}$ ed., Vol. 1, pp. 466485). Hoboken, NJ: John Riley \& Son.

Vliegenthart, R. (2012). Framing in mass communication research: An overview and assessment. Sociology Compass, 6(12), 937-948.

Weaver, H. N. (2009). Reflections on violence in the lives of Native American Women. Journal of Interpersonal Violence, 24(9), 1552-1563.

Weston, M. A. (1996). Native Americans in the news: Images of Indians in the twentieth century press. Westport, CO: Greenwood Press.

Williams, R. A. (1989). Documents of barbarism: The contemporary legacy of European racism and colonialism in the narrative traditions of federal Indian law. Arizona Law Review, 31, 237-278.

Williams, F. \& Monge, P. (2001). Reasoning with statistics: How to read quantitative research (5 $5^{\text {th }}$ ed.). Harcourt College Publishers. 


\section{Appendix A: Code Sheet for Frame Analysis}

List the following information in the Microsoft Excel code sheet used for the specific media genre (mainstream, Native American, tribal):

\section{Part 1: Publications and Articles}

1. Article code number:

2. Publication name:

2a: If mainstream press: list whether the outlet is local or national:

2b: If Native American press: list the specific organization or individual that owns the outlet:

2c: If tribal press: list the specific tribe, band, or nation that owns the outlet:

3. Publication type (magazine, newspaper, newsletter):

4. Location of main office of publication (city and state):

5. Article name:

6. Article type (news or editorial):

7. Article date of publication:

8. Name of reporter (if given):

9. Is the article an Associated Press or wire story? (list below):

\section{Part 2: Frames and Themes}

10. Literature frames found in the article (conflict or "Indian as other"):

11. Emergent frames found in the article: 
11a: If emergent frames are found, what themes are identified in the article?

12. If no frames are identified, what information is provided in the article?

13. Linguistic structures used in the article (lexical features, modality, implied claims or meanings, in-group/out-group language, transitivity and subjects) and specific descriptions/examples:

\section{Part 3: Sources and Source Use}

14. Total number of person sources used in the article:

15. Name of source:

16. Occupational title (given in the article):

17. Organization that the source represents (given in the article):

18. "Occupational Category":

19. Source attribution (direct or indirect):

19a. If indirect attribution, list how the source was attributed in the article (e.g.; at a Congressional meeting, in a written statement): 


\section{Appendix B: Mainstream Press Outlets}

\begin{tabular}{|l|l|l|l|}
\hline Name of Publication & $\begin{array}{l}\text { Local / National } \\
\text { Outlet }\end{array}$ & $\begin{array}{l}\text { Number of } \\
\text { Articles }\end{array}$ & Location of Main Office \\
\hline Bemidji Pioneer & Local & 1 & Bemidji, Minnesota \\
\hline Bismarck Tribune & Local & 3 & Bismarck, North Dakota \\
\hline Charleston Gazette & Local & 1 & Charleston, West Virginia \\
\hline Christian Science Monitor & National & 1 & Boston, Massachusetts \\
\hline Daily Oklahoman & Local & 2 & Oklahoma City, Oklahoma \\
\hline Daily Republic & Local & 1 & Mitchell, South Dakota \\
\hline Desert News (Desert Morning News) & Local & 1 & Salt Lake City, Utah \\
\hline Farmington Daily Times & Local & 2 & Farmington, New Mexico \\
\hline Grand Forks Herald & Local & 3 & Grand Forks, North Dakota \\
\hline Humboldt Journal & Local & 1 & Humboldt, South Dakota \\
\hline Muskogee Phoenix & Local & 5 & Muskogee, Oklahoma \\
\hline New York Times & National & 2 & New York City, New York \\
\hline Nowota Star & Local & 1 & Nowota, Oklahoma \\
\hline Pittsburg Post-Gazette & Local & 1 & Pittsburgh, Pennsylvania \\
\hline Roll Call & National & 2 & Washington, D.C. \\
\hline Salt Lake Tribune & Local & 1 & Salt Lake City, Utah \\
\hline Spokesman Review & Local & 1 & Spokane, Washington \\
\hline Sunday News & Local & 1 & Lancaster, Pennsylvania \\
\hline Turtle Mountain Star & Local & 3 & Rolla, North Dakota \\
\hline Washington Post & National & 3 & Washington, D.C. \\
\hline
\end{tabular}




\section{Appendix C: Native American and Tribal Press Outlets}

\begin{tabular}{|l|l|l|l|l|}
\hline Name of Publication & $\begin{array}{l}\text { Native American } \\
\text { or Tribal Outlet }\end{array}$ & Media Ownership & $\begin{array}{l}\text { Number of } \\
\text { Articles }\end{array}$ & $\begin{array}{l}\text { Location of } \\
\text { Main Office }\end{array}$ \\
\hline $\begin{array}{l}\text { Au-Authm Action } \\
\text { News }\end{array}$ & Tribal & $\begin{array}{l}\text { Salt River Pima- } \\
\text { Maricopa Tribe }\end{array}$ & 6 & $\begin{array}{l}\text { Scottsdale, } \\
\text { Arizona }\end{array}$ \\
\hline Char-Koosta News & Tribal & $\begin{array}{l}\text { Confederated Salish } \\
\text { and Kootenai Tribes }\end{array}$ & 1 & $\begin{array}{l}\text { Pablo, } \\
\text { Montana }\end{array}$ \\
\hline Cherokee Phoenix & Tribal & Cherokee Nation & 2 & $\begin{array}{l}\text { Tahlequah, } \\
\text { Oklahoma }\end{array}$ \\
\hline $\begin{array}{l}\text { Confederated } \\
\text { Umatilla Journal }\end{array}$ & Tribal & $\begin{array}{l}\text { Confederated Tribes } \\
\text { of the Umatilla Indian } \\
\text { Reservation }\end{array}$ & 3 & $\begin{array}{l}\text { Pendleton, } \\
\text { Oregon }\end{array}$ \\
\hline Navajo Times & Tribal & Navajo Tribal Council & 1 & $\begin{array}{l}\text { Window Rock, } \\
\text { Arizona }\end{array}$ \\
\hline $\begin{array}{l}\text { Native American } \\
\text { Times }\end{array}$ & Native American & Lisa Snell (Cherokee) & 7 & $\begin{array}{l}\text { Tulsa, } \\
\text { Oklahoma }\end{array}$ \\
\hline $\begin{array}{l}\text { News from Indian } \\
\text { Country }\end{array}$ & Native American & $\begin{array}{l}\text { Indian Country } \\
\text { Communications }\end{array}$ & 1 & $\begin{array}{l}\text { Hayward, } \\
\text { Wisconsin }\end{array}$ \\
\hline Seminole Tribune & Tribal & Seminole Tribe & 3 & $\begin{array}{l}\text { Hollywood, } \\
\text { Florida }\end{array}$ \\
\hline Sho-Ban News & Native American & $\begin{array}{l}\text { Fort Hall Business } \\
\text { Council }\end{array}$ & 1 & $\begin{array}{l}\text { Fort Hall, } \\
\text { Idaho }\end{array}$ \\
\hline $\begin{array}{l}\text { The Circle: News } \\
\text { from an American } \\
\text { Indian Perspective }\end{array}$ & Native American & $\begin{array}{l}\text { Minneapolis American } \\
\text { Indian Center }\end{array}$ & 1 & $\begin{array}{l}\text { Minneapolis, } \\
\text { Minnesota }\end{array}$ \\
\hline
\end{tabular}




\section{Appendix D: Reference List for Article Data}

(2012, October 18). VAWA - Violence against native women gaining global attention Will Congress do something? Au-Authm Action News. Scottsdale, Arizona.

Retrieved from

http://search.proquest.com.proxy.lib.pdx.edu/docview/1150193247?accountid=1326

5.

(2013, March). VAWA passes Senate, heads to House. Cherokee Phoenix. Tahlequah,

Oklahoma. Retrieved from

http://search.proquest.com/docview/1349577059?accountid=13265.

(2013, March 7). Salazar, Washburn commend passage of Violence Against Women Act. Au-Authm Action News. Scottsdale, Arizona. Retrieved from http://search.proquest.com/docview/1324612338?accountid=13265.

(2013, April). VAWA bill signed into law. Cherokee Phoenix. Tahlequah, Oklahoma. Retrieved from http://search.proquest.com/docview/1353609499?accountid=13265.

(2013, March 29). Alaskans object to VAWA provisions. Seminole Tribune. Hollywood, Florida. Retrieved from http://search.proquest.com/docview/1350918342?accountid=13265.

(2014, February 20). Pascua Yaqui Tribe of Arizona to be one of three tribes to implement special domestic violence criminal jurisdiction under VAWA 2013. Au- 
Authm Action News. Scottsdale, Arizona. Retrieved from http://search.proquest.com/docview/1508483793?accountid=13265.

Abrams, J. (2013, March 1). Republicans offer deal on American Indian courts. Native American Times. Tulsa, Oklahoma. Retrieved from http://search.proquest.com/docview/1319251852?accountid=13265.

Arnold, G. S. (2014, January). Umatilla Tribal Court - Leading Indian Country in its approach to criminal jurisdiction. Confederated Umatilla Journal. Pendleton, Oregon. Retrieved from http://search.proquest.com/docview/1490685490?accountid=13265.

Edmo-Suppah, L. (2011, November 7). Stand Against Violence Empower Native Women Act introduced in Congress. Sho - Ban News, p. 1. Fort Hall, Idaho. Retrieved from http://search.proquest.com.proxy.lib.pdx.edu/docview/912653830?accountid=13265

Erdrich, L. (2013, February 27). Rape on the reservation. The New York Times. New York City, New York. Retrieved from http://www.lexisnexis.com/lnacui2api/api/version1/getDocCui?lni=57VC-8C41DXY4-

$\mathrm{X} 31 \mathrm{D} \& \mathrm{csi}=8411 \& \mathrm{hl}=\mathrm{t} \& \mathrm{hv}=\mathrm{t} \& \mathrm{hnsd}=\mathrm{f} \& \mathrm{hns}=\mathrm{t} \& \mathrm{hgn}=\mathrm{t} \& o c=00240 \&$ perma $=$ true.

Gamboa, S. (2012, March 9). Tribes make push for Violence Against Women Act. The Salt Lake Tribune. Salt Lake City, Utah. Retrieved from 
http://www.lexisnexis.com/lnacui2api/api/version1/getDocCui?lni=554V-NVP1DYT4-

V1FT\&csi=8411\&hl=t\&hv=t\&hnsd=f\&hns=t\&hgn=t\&oc=00240\&perma=true

Gamboa, S. (2012, March 16). Tribes encourage support for Violence Against Women Act. Native American Times. Tulsa, Oklahoma. Retrieved from http://search.proquest.com.proxy.lib.pdx.edu/docview/993086715?accountid=13265

Haga, C. (2013, March 29). Rep. Cramer disputes account of "tirade" during meeting with American Indians, but apologizes for tone. Grand Forks Herald. Grand Forks, North Dakota. Retrieved from http://www.lexisnexis.com.proxy.lib.pdx.edu/lnacui2api/api/version1/getDocCui?lni $=582 \mathrm{~V}-5 \mathrm{~F} 81-\mathrm{JC} 6 \mathrm{P}-$

$\mathrm{C} 08 \mathrm{G} \& \mathrm{csi}=8411 \& \mathrm{hl}=\mathrm{t} \& \mathrm{hv}=\mathrm{t} \& \mathrm{hnsd}=\mathrm{f} \& \mathrm{hns}=\mathrm{t} \& \mathrm{hgn}=\mathrm{t} \& \mathrm{oc}=00240 \&$ perma $=$ true.

Haga, C. (2013, March 30). Cramer's apology not accepted; Spirit Lake Tribal Council denounces remarks by congressman. Grand Forks Herald. Grand Forks, North Dakota. Retrieved from http://www.lexisnexis.com.proxy.lib.pdx.edu/lnacui2api/api/version1/getDocCui?lni $=5832-4$ C41-DYNS -

$31 \mathrm{GR} \& \mathrm{csi}=8411 \& \mathrm{hl}=\mathrm{t} \& \mathrm{hv}=\mathrm{t} \& \mathrm{hnsd}=\mathrm{f} \& \mathrm{hns}=\mathrm{t} \& \mathrm{hgn}=\mathrm{t} \& \mathrm{oc}=00240 \&$ perma $=$ true. 
Horwitz, S. (2014, August 3). Senator from Alaska reverses her divisive stance on women's law. The Washington Post. Washington, D.C. Retrieved from http://www.lexisnexis.com.proxy.lib.pdx.edu/lnacui2api/api/version1/getDocCui?lni $=5 \mathrm{CTP}-\mathrm{P} 5 \mathrm{C} 1-\mathrm{JBFW}-$

C3FF\&csi $=8411 \& \mathrm{hl}=\mathrm{t} \& \mathrm{hv}=\mathrm{t} \& \mathrm{hnsd}=\mathrm{f} \& \mathrm{hns}=\mathrm{t} \& \mathrm{hgn}=\mathrm{t} \&$ oc $=00240 \&$ perma=true

Krehbiel-Burton, L. (2013, February 22). Senate votes to renew VAWA. Native American Times. Tulsa, Oklahoma. Retrieved from http://search.proquest.com/docview/1314913051 ?accountid=13265.

Krehbiel-Burton, L. (2013, March 8). Indian Country leaders, advocates celebrate passage of VAWA. Native American Times. Tulsa, Oklahoma. Retrieved from http://search.proquest.com/docview/1321769703?accountid=13265.

LaDuke, W. (2013, February 25). Violence Against Women Act: Why Native women matter; other views. Turtle Mountain Star. Rolla, North Dakota. Retrieved from http://www.lexisnexis.com/lnacui2api/api/version1/getDocCui?lni=5DJ5-PFR1JDTS-

$\mathrm{G} 256 \& \mathrm{csi}=8411 \& \mathrm{hl}=\mathrm{t} \& \mathrm{hv}=\mathrm{t} \& \mathrm{hnsd}=\mathrm{f} \& \mathrm{hns}=\mathrm{t} \& \mathrm{hgn}=\mathrm{t} \& \mathrm{oc}=00240 \&$ perma $=$ true.

Mapes, L. V. (2013, February 25). Indians seek powers on domestic violence. Pittsburgh Post-Gazette. Pittsburgh, Pennsylvania. Retrieved from http://www.lexisnexis.com/lnacui2api/api/version1/getDocCui?lni=57TY-WHK1- 
JC8R-

$31 \mathrm{MX} \& \mathrm{csi}=8411 \& \mathrm{hl}=\mathrm{t} \& \mathrm{hv}=\mathrm{t} \& \mathrm{hnsd}=\mathrm{f} \& \mathrm{hns}=\mathrm{t} \& \mathrm{hgn}=\mathrm{t} \& \mathrm{oc}=00240 \&$ perma=true.

Mapes, L. V. (2013, March 15). Domestic violence: Act gives tribes more police powers. Charleston Gazette. Charleston, West Virginia. Retrieved from http://www.lexisnexis.com.proxy.lib.pdx.edu/lnacui2api/api/version1/getDocCui?lni $=57 \mathrm{YV}-\mathrm{VGG} 1-\mathrm{JCB} 7-$

$14 \mathrm{~T} 0 \& \mathrm{csi}=8411 \& \mathrm{hl}=\mathrm{t} \& \mathrm{hv}=\mathrm{t} \& \mathrm{hnsd}=\mathrm{f} \& \mathrm{hns}=\mathrm{t} \& \mathrm{hgn}=\mathrm{t} \& \mathrm{oc}=00240 \&$ perma $=$ true.

Powers, M. (2012, July 29). To Congress: Reauthorize Violence Against Women Act. Sunday News. Lancaster, Pennsylvania. Retrieved from http://www.lexisnexis.com/lnacui2api/api/version1/getDocCui?lni=5677-JHS1JC8K-

B3G3\&csi=8411\&hl=t\&hv=t\&hnsd=f\&hns=t\&hgn=t\&oc=00240\&perma=true.

Ross, D. (2012, April 27). Noem opposes listing Native women in anti-violence bill. The Daily Republic. Mitchell, South Dakota. Retrieved from http://www.lexisnexis.com/lnacui2api/api/version1/getDocCui?lni=55H5-YPS1JC6P$\mathrm{C} 065 \& \mathrm{csi}=8411 \& \mathrm{hl}=\mathrm{t} \& \mathrm{hv}=\mathrm{t} \& \mathrm{hnsd}=\mathrm{f} \& \mathrm{hns}=\mathrm{t} \& \mathrm{hgn}=\mathrm{t} \& \mathrm{oc}=00240 \&$ perma $=$ true.

Strong, J. (2012, May 16). VAWA hits snag in House. Roll Call. Washington, D.C. Retrieved from http://www.lexisnexis.com/lnacui2api/api/version1/getDocCui?lni=55N6-W8D1- 
JCBD-

$31 \mathrm{XG} \& \mathrm{csi}=8411 \& \mathrm{hl}=\mathrm{t} \& \mathrm{hv}=\mathrm{t} \& \mathrm{hnsd}=\mathrm{f} \& \mathrm{hns}=\mathrm{t} \& \mathrm{hgn}=\mathrm{t} \& \mathrm{oc}=00240 \&$ perma=true

Weisman, J. (2013, February 11). Measure to protect women stuck on tribal land issue. The New York Times. New York City, New York. Retrieved from http://www.lexisnexis.com/lnacui2api/api/version1/getDocCui?lni=57PY-RM11JBG3-

62R0\&csi=8411\&hl=t\&hv=t\&hnsd=f\&hns=t\&hgn=t\&oc=00240\&perma $=$ true.

Wilson, C. (2013, April). Expanded Violence Against Women Act to cover some Indian women. The Circle: News from an American Indian Perspective. Minneapolis, Minnesota. Retrieved from http://search.proquest.com/docview/1335091967?accountid=13265. 